This is an electronic reprint of the original article. This reprint may differ from the original in pagination and typographic detail.

Author(s): Ukpabi, Dandison; Karjaluoto, Heikki

Title: $\quad$ Consumers' acceptance of information and communications technology in tourism : A review

Year: $\quad 2017$

Version:

Please cite the original version:

Ukpabi, D., \& Karjaluoto, H. (2017). Consumers' acceptance of information and communications technology in tourism : A review. Telematics and Informatics, 34(5), 618-644. https://doi.org/10.1016/j.tele.2016.12.002

All material supplied via JYX is protected by copyright and other intellectual property rights, and duplication or sale of all or part of any of the repository collections is not permitted, except that material may be duplicated by you for your research use or educational purposes in electronic or print form. You must obtain permission for any other use. Electronic or print copies may not be offered, whether for sale or otherwise to anyone who is not an authorised user. 


\section{Accepted Manuscript}

Consumers' acceptance of information and communications technology in tourism: A review

Dandison C. Ukpabi, Heikki Karjaluoto

PII:

S0736-5853(16)30336-7

DOI: http://dx.doi.org/10.1016/j.tele.2016.12.002

Reference: TELE 894

To appear in:

Telematics and Informatics

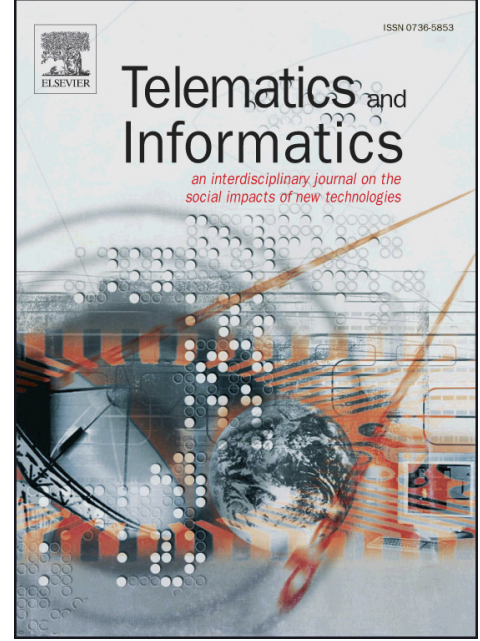

Received Date: $\quad 22$ July 2016

Revised Date: $\quad 10$ October 2016

Accepted Date: 6 December 2016

Please cite this article as: Ukpabi, D.C., Karjaluoto, H., Consumers' acceptance of information and communications technology in tourism: A review, Telematics and Informatics (2016), doi: http://dx.doi.org/10.1016/j.tele. 2016.12.002

This is a PDF file of an unedited manuscript that has been accepted for publication. As a service to our customers we are providing this early version of the manuscript. The manuscript will undergo copyediting, typesetting, and review of the resulting proof before it is published in its final form. Please note that during the production process errors may be discovered which could affect the content, and all legal disclaimers that apply to the journal pertain. 
Title:

Consumers' acceptance of information and communications technology in tourism: A review

\section{Authors:}

Dandison C. Ukpabi

University of Jyvaskyla

Finland

\section{Heikki Karjaluoto}

University of Jyvaskyla

Finland 


\title{
Consumers' acceptance of information and communications technology in tourism: A review
}

Author 1

Author 2

\begin{abstract}
The impact of information and communications technology (ICT) in tourism (e-tourism) has altered the ways tourism services are accessed and consumed. Ubiquitous and highly innovative ICTs provide different channels for consumers to use tourism services; thus, studies on e-tourism are numerous and fragmented. Different factors account for how consumers embrace these channels. The purpose of this study is to review studies on consumers' acceptance or adoption of e-tourism in order to group the studies, synthesize the theories, models and frameworks used and identify the antecedents influencing consumers' $e$ tourism acceptance and usage. A total of 71 studies from 2005-2016 (inclusive) from both tourism-based and non-tourism-based journals were selected, synthesized, and included. Based on their contexts, similarity and relevance, the 71 studies were segregated into three distinct groups. This study found that research among the groups is uneven. Implications and research directions are suggested.
\end{abstract}

Keywords: e-tourism, ICT, website, social media, mobile technology

\section{Introduction}

The ubiquity of computer systems and the availability of the internet have provided unhindered access to consumers of tourism services. E-tourism has transformed the tourism and hospitality industry and greatly impacted all its sectors. For instance, revenue from online travel bookings stood at $\$ 340$ billion in 2015 (Statistica, 2016). Therefore, making travel arrangements - that is, reserving and booking travel and tourism products - online has become a significant commercial sector (Wen, 2012). Similarly, social media have also provided a means through which consumers obtain information about tourism services. Social media platforms contain both positive and negative statements and reviews about destinations and services shared by consumers. The influence of social media on consumers' acceptance and usage of tourism services has been underscored by the increasing number of reviews on social media platforms, e.g., TripAdvisor. Currently, on TripAdvisor, there are 320 million reviews and opinions from 96 million marketable members worldwide; 200 new posts are made every minute (TripAdvisor, 2016).

Additionally, the deployment of mobile technology has fundamentally transformed tourism offerings. Mobile technology enhances transactions through mobile devices and provides guides, even when the tourist is at the destination. Mobile apps are reportedly the $7^{\text {th }}$ most downloaded apps, with $60 \%$ of global smartphone users downloading travel apps onto their devices and $45 \%$ in this group using these apps regularly to plan travel (GoodWorkLabs, 2016).

Information and communications technology (ICT) has permeated virtually every sector. However, consumers adopt these emerging technologies in different ways. In an attempt to understand these differences and to explain the adoption process and their antecedents, 
researchers have proposed different theories, models and frameworks. Some of these theories were drawn from the social-psychological domains, e.g., Fishbein and Ajzen's (1975) theory of reasoned action (TRA) and Ajzen's (1991) theory of planned behavior (TPB). Some originated predominantly in the information systems (IS) field, e.g., Davis' (1989) technology acceptance model (TAM) and Venkatesh et al.'s (2003) unified theory of acceptance and use of technology (UTAUT). Similarly, scholars have used these theories to explain the intentions (Amaro \& Duarte, 2015; Sahli \& Legoherel, 2015) and usage of ICT in tourism (Herrero \& Martin, 2012; Ku \& Chen, 2015).

Studies that have examined different ways consumers adopt ICT in tourism and hospitality services abound, including such topics as factors influencing consumers' travel purchases online (Al-hawari \& Mouakket, 2012; Escobar-Rodriguez et. al., 2014; Kim et al., 2013; Lee \& Cranage, 2011; Nunko \& Ramkisson, 2013; Sahli \& Legoherel, 2015), website design and booking intentions ( $\mathrm{Ku} \& \mathrm{Chen}, 2015$; Wu et. al., 2011), the role of social media in booking travel online (Ayeh et al., 2013; Book et al., 2015; Parra-Lopez et al., 2011), and the role of mobile technology on travel planning and use (Chang et al., 2016; Kim et al., 2015; Lai, 2015; Okazaki \& Hirose, 2009).

Several reviews have been conducted on the application of ICT in tourism (Appendix II). However, no apparent review has taken a deeper look at the dynamics of consumers' adoption of ICT in tourism services. Our study is unique because consumers' adoption is a critical success factor for the deployment of ICT in tourism, and synthesizing the theories, frameworks, models and antecedents used in these studies is crucial for both scholars and practitioners. Additionally, the dynamic nature of ICT - especially as it concerns tourism requires a constant update in the literature, as this helps practitioners and scholars to keep abreast of the field (Law et al., 2009). Buhalis \& Law (2008), for example, comprehensively analyzed e-tourism publications but provided no grouping for scalability. As such, they called for the extension of future reviews to non-tourism journals and a conceptual grouping of studies. Similarly, Law et al., (2009) suggested that future reviews should analyze studies based on geographical spread to determine the extent of ICT adoption in tourism and hospitality services. Finally, Law et al. (2014) suggested that future reviews analyze the theories used in these studies.

Consequently, this study aims to fill the above-mentioned gaps in the literature and to understand the factors influencing consumers' adoption of e-tourism. Specifically, the objectives of this study are to achieve the following:

- Identify and synthesize the antecedents of consumers' adoption of e-tourism;

- Provide a classification framework for consumers' adoption of e-tourism based on previous studies;

- Identify the theories, models and frameworks used in order to synthesize their applications in various domains.

- Analyze the geographical spread of studies identifying the behavioral dynamics of consumers with respect to ICT adoption in tourism.

This study is significant for both scholars and practitioners. First, the grouping of the studies will offer new research opportunities, thus revealing under-researched areas (Shaikh \& Karjaluoto, 2015). Second, the synthesis of the theories, models and frameworks will provide a solid theoretical background for subsequent research in this area (Okoli \& Schabram, 2010). Third, the analysis of the antecedents and concepts, in line with Webster \& Watson (2002), will enunciate the present state of research and serve as a pool for subsequent studies. 
Fourth, this will expose practitioners to underpinning practical antecedents that may serve as levers to attract more consumers, thus allowing them to remain competitive in business. The remainder of the study is organized as follows: Section 2 traces the background of consumers' adoption of e-tourism; Section 3 describes the research methods; Section 4 presents the results; Section 5 provides discussions and implications, contributions of the study, limitations and future research directions.

\section{Background on e-tourism and its adoption by consumers}

Because tourism is an information-intensive sector, a central reservation system was often used to store and retrieve information and conduct transactions (Buhalis, 2000), thus creating a central customer database. Booking in tourism services depended on travel agents, who mediated the relationship between tourism firms and customers (Buhalis, 1996). However, the ubiquity of computer systems and the emergence of the internet transformed and revolutionized the way tourism transactions are conducted (Buhalis \& Jun, 2011). The internet has become a place for consumers to search for tourism-related information, purchase tourism products and services, and obtain others' opinions.

Uncertainty about the safety of online tourism bookings and transactions influenced early streams of research to focus on security (Kim, Ma \& Kim, 2006), privacy (Lee \& Cranage, 2011) and trust (Wu \& Chang, 2005). Particularly, security was considered the most important consideration for online booking (Kim et al. 2006; Ryan \& Rao, 2008). Increases in consumers' adoption and use of web-based platforms in tourism and hospitality services created website quality concerns, thus influencing research on website design quality $(\mathrm{Ku} \&$ Chen, 2015). Ease of navigation and information quality became important considerations for attracting and retaining customers (Wong \& Law, 2005; Kaplanidou \& Vogt (2006), as userfriendly websites enhanced information search and helped tourists arrive at quick decisions (Ku \& Chen, 2015). Meanwhile, Destination Marketing Organizations (DMO) realized that the internet offered abundant opportunities for their operations. As a result, websites were designed to reflect destination attributes, thus influencing the perceived image of the destination and creating a virtual experience for the consumer (Sparks \& Pan, 2009). Importantly, as argued by Chow \& Murphy (2011), actual travel and the intention to travel were influenced by sightseeing, culture and heritage activity; consequently, consumers were attracted to destination websites that reflected these attributes.

Moreover, the emergence of Web 2.0 redefined consumers' adoption of e-tourism. Web 2.0 is defined as "a wide array of electronic applications (e.g., social networks, review websites, blogs, interactive websites and photo- and video-sharing platforms), which facilitate interactions among individuals and among companies and users" (Herrero, et al., 2015, p.1574). Through these platforms, especially social media, consumers easily form communities of members who share similar interests in a structured set of social relationships (Zhu et al., 2016). Thus, experiences with tourism products and services are shared in the form of photos, comments and reviews and are easily accessed by others (Ho \& Lee, 2015). Marketers also share content to promote their products; however, consumer-generated media are perceived to be more trusted and sincere, constituting the real experience(s) of the creator (Wang, 2012). Consequently, reading content about tourism products and services has become an important pre-trip decision-making process (Tsao et al., 2015).

Furthermore, the market penetration of mobile technology (Shaikh \& Karjaluoto, 2016) also influenced the adoption of tourism products and services. The ubiquity, flexibility, personalization and dissemination features of mobile technology make it a veritable tool for 
both marketers and consumers in tourism and hospitality services (Kim et al., 2008). For consumers, the functionality of mobile technology, such as the ease of access to travel information and trip guides, is an essential feature of its increased adoption, whereas for marketers, it is the opportunity to send marketing messages to a targeted audience. However, individual differences determine mobile technology adoption in tourism and hospitality services. For instance, Kim et al., 2008) reported that experienced and frequent travelers have a higher rate of mobile technology adoption than inexperienced and infrequent travelers.

A thorough literature search reveals two main applications of the e-tourism concept. First, the use of the internet in tourism services (Fodor \& Werthner, 2005; Cardoso \& Lange, 2007), and second, the use of mobile applications in tourism (Siricharoen, 2008; Sebastia et al., 2009; García-Crespo, 2009). However, Buhalis \& Deimezi (2004, p.103) posited, "e-tourism reflects the digitalization of all processes and value chains in the tourism, travel, hospitality and catering industries", thus implying all uses of ICT in tourism-related firms. In the context of this study, e-tourism is defined as the ICT-enabled means by which consumers access and consume tourism and hospitality products and services. Our use of 'adoption' in this study implies consumers' intention to use and use of e-tourism, and the terms 'tourist' and 'consumers' imply those who consume tourism products.

\section{Research Methodology}

\subsection{Literature Search}

Previous literature reviews (Appendix II) on e-tourism were thoroughly analyzed and synthesized; a plan based on their recommendations was drawn up. The first suggestion was to identify keywords for the basis of a literature search and extraction. The second recommendation was the establishment of literature inclusion criteria. The third was the classification of literature search into three major areas based on similarity, contexts and relevance. This suggestion was considered particularly important because it will provide a guiding structure for the study and identify gaps and challenges. Major search terms include 'e-tourism', 'e-tourism adoption', 'online tourism adoption', 'tourism website adoption', 'social media tourism adoption', 'Web 2.0 adoption in tourism', 'mobile tourism adoption', 'online destination image' and 'online tourism intention and use'. Google Scholar and Web of Science were used first. Further search included ScienceDirect, SAGE, Wiley, Springer, Emerald, Taylor \& Francis, JSTOR and Inderscience. To take full advantage of this exercise, a ten-year period was set from 2005 to 2016. To avoid duplication, all the studies were saved into one folder with the title of each study as its file name. Therefore, it was easy to detect studies that appeared more than once; these duplicates were subsequently deleted.

\subsection{Literature Selection}

The literature search yielded a large number of studies. To limit the studies to a manageable size, the researchers speed-read each article's abstract, introduction, methodology and texts from relevant sections to ascertain its relevance and potential for inclusion (Lu \& Stepchenkova, 2015). Only accepted studies were fully read and analyzed (Appendix 1). Guided by Baron et al. (2014), who posited that stability, reproducibility and accuracy are pillars of a good literature review, the inclusion criteria required that each included study must be a peer-reviewed article, consumer-based, and empirical, include measures for independent and dependent variables, have a defined sample size and provide detailed results of data analysis. Additionally because tourism is a large and heterogeneous industry (WTTC, 2016), capturing all e-tourism-related research would make the study unwieldy. Consequently, we limited our literature inclusion to e-tourism studies in hospitality and 
accommodation, catering, events, travel and heritage and government. After the screening stage, 71 studies were found to be useful for the study.

\subsection{Justification for classification of the literature and framework}

Based on one of our objectives, studies were classified according to similarity, contexts and relevance. Consumers' adoption of e-tourism was expressed mainly through browsing, reservation, booking and security concerns on tourism and hospitality firm websites (e.g., Amaro \& Duarte, 2015). Another important channel for consumer adoption of e-tourism is social media, otherwise called Web 2.0 (e.g. Casaló et al., 2010). Finally, a critical analysis of the studies revealed a very important area of e-tourism, that is, mobile technology (e.g., mobile apps and devices) in tourism and hospitality services (e.g., Kim et al., 2015). Based on the above, we classify the 71 studies into three groups comprising Consumer Adoption of Web-Based Services in Tourism (CAWST), Consumer Adoption of Social Media in Tourism (CASMT) and Consumer Adoption of Mobile Information Services in Tourism (CAMIST), as shown in figure 1.

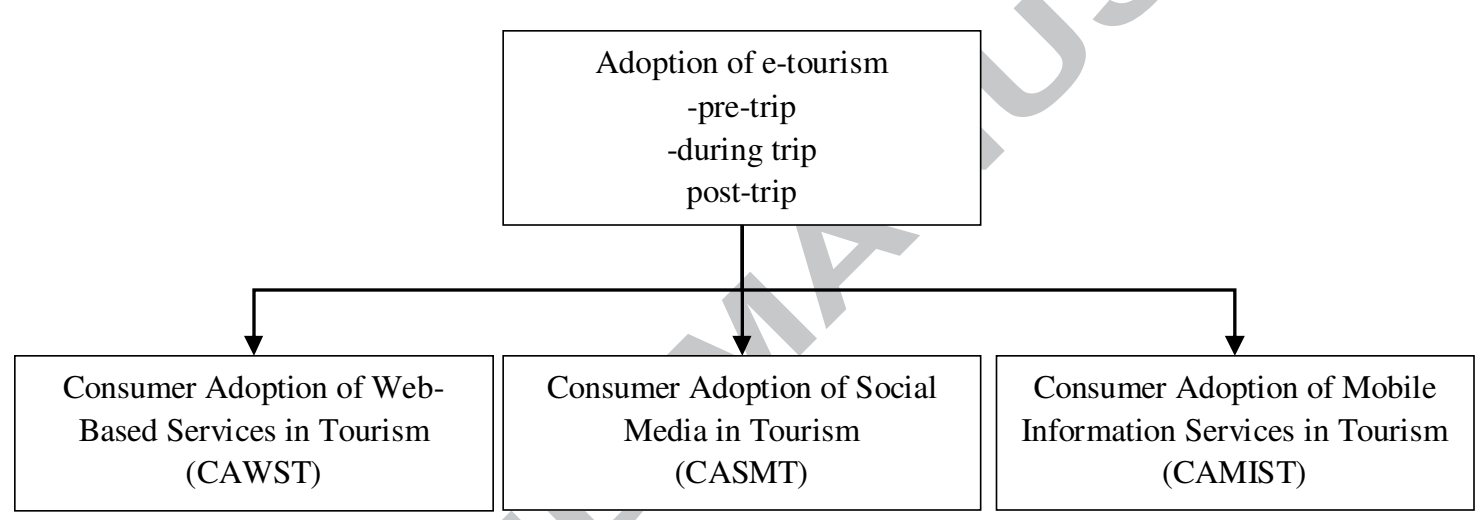

Figure 1. Classification framework for consumers' adoption of ICT in tourism

The first classification, CAWST, covers the services consumers derive from tourism and hospitality organizations' websites. This classification comprises research on consumers' intentions to purchase as influenced by website functionality, navigability, interactivity, security and privacy concerns. Specifically, it includes tourism information search (Kaplanidou \& Vogt, 2006; Lin, 2010), reservation and booking (Kucukusta et al., 2015), and online shopping for travel services (Kamarulzaman, 2007; Kim et al., 2009; Wong \& Law, 2005). Additionally, it covers studies on tourism websites' influence on destination image (Chung et al., 2015). The second classification, CASMT, covers studies on social media's influence on consumers' adoption of tourism and hospitality services. Social media platforms include virtual communities (e.g., Lonely Planet), media-sharing tools (e.g., YouTube), blogs (e.g., Xanga.com), microblogs (e.g., Twitter), review sites (e.g., TripAdvisor), and social networking sites (e.g., Facebook). Lastly, CAMIST covers studies on mobile information systems' influence on consumers' adoption of tourism and hospitality services. Specifically, it covers mobile tourism shopping (Kim et al., 2015), mobile travel apps (Lai, 2015), mobile internet (Okazaki \& Hirose, 2009), smartphones and tablets (No \& Kim, 2014) and recommender systems (Chung et al., 2014). 


\subsection{Identification of variables of interest}

As noted earlier, the study is consumer-based; therefore, variables of interest were factors influencing consumers' adoption of ICT in tourism. The identification of the variables followed the classification of the studies. Thereafter, we adopted Webster \& Watson's (2002) concept-driven approach and following the examples of previous reviews (Cheung \& Thadani, 2012; King, Racherla \& Bush, 2014; Shaikh \& Karjaluoto, 2015), we manually derived these variables from the theories, models and frameworks used in each of the studies.

\section{Results}

\subsection{General Findings (statistics)}

The review of the 71 studies was drawn from 16 tourism and 14 non-tourism journals (Appendix III). The journals were extracted from five databases (Figure 2). The Eastern Asia region comprising China, Hong Kong, Japan, Republic of Korea and Taiwan contributed 37 $(52 \%)$ studies, with Taiwan alone offering 15 (21\%). Only one (1.4\%) study came from South Asia (the Indian Sub-continent); it was conducted in Singapore.

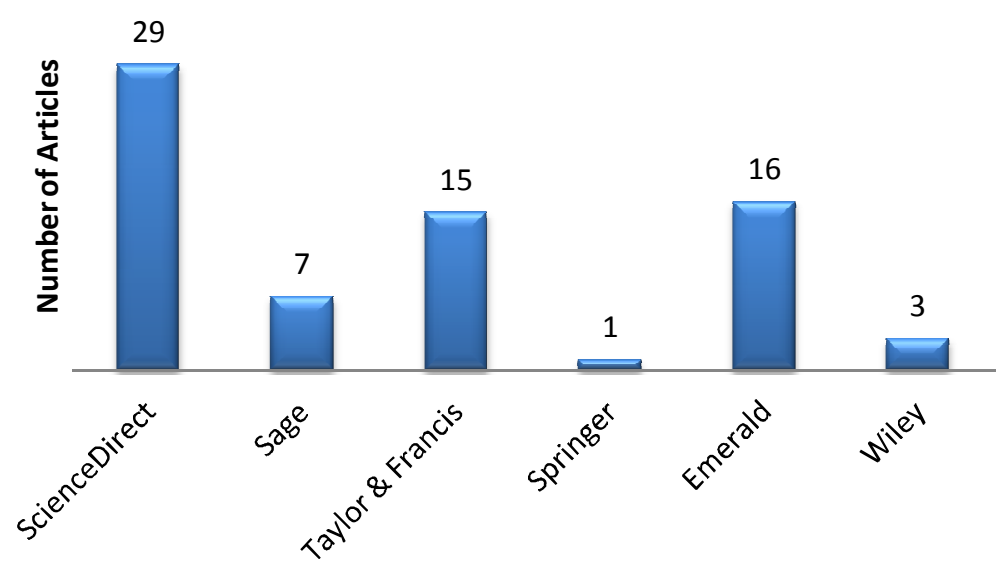

Figure 2. Database distribution of articles

Europe offered 14 studies (19.7\%), with Spain alone providing nine (12.6\%). The United States of America (USA) had $10(14 \%)$ and Middle East, four (5.6\%), mainly from the United Arab Emirates (UAE) and Iran. Africa contributed one study (1.4\%), which was conducted in Tunisia. The highest number of studies were published in 2015, 2013 and 2012, with 12 (16.9\%), $11(15 \%)$ and 10 (14\%), respectively. 2005 and 2006 recorded the fewest publications, with two (2.8\%) in each year. However, because this study was conducted in early 2016, only one study was reflected in this year, as indicated by a dashed line (Figure 3 ).

Different sampling techniques were utilized, however, the majority of the studies adopted the convenience sampling method (e.g., Wen, 2013). To obtain responses, various methods were employed, including web-based and email communication (59\%), on-site and face-to-face contact (34\%), and postal comunication (1\%). Six percent used both web-based/email and onsite methods (figure 4). Samples comprised residents, tourists, students, internet users, and international tourists. The average sample size was 548 . 


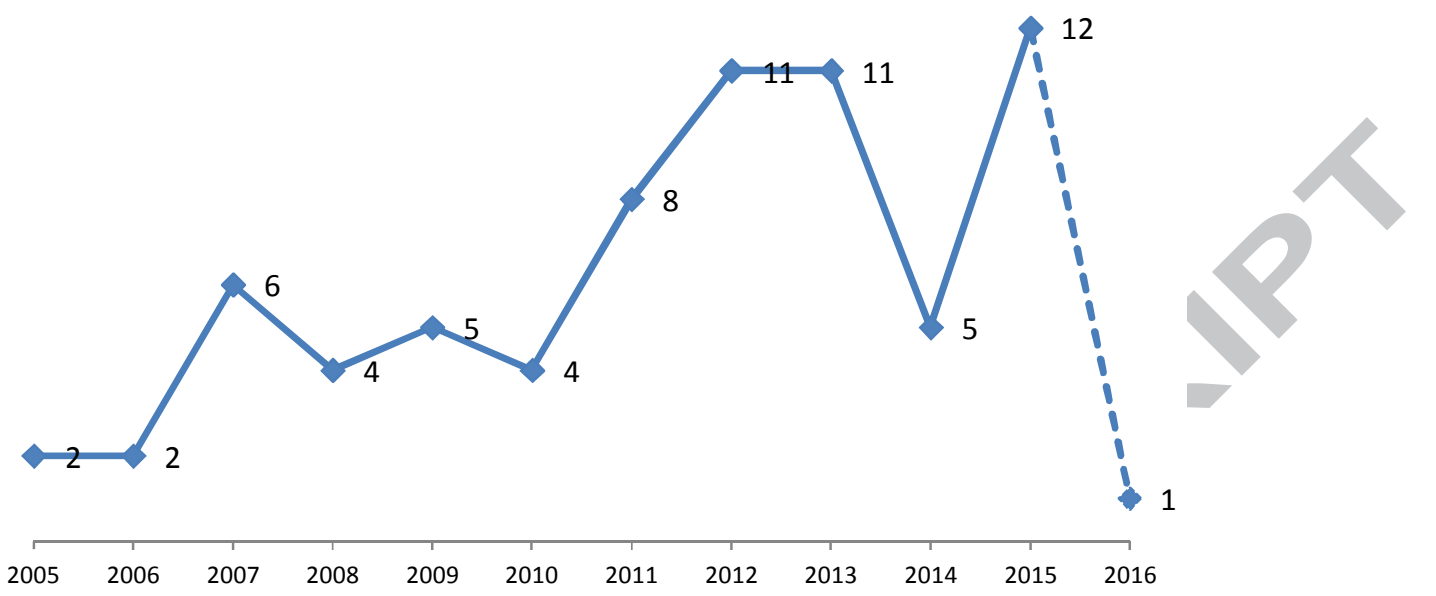

Figure 3. Year-wise distribution of articles

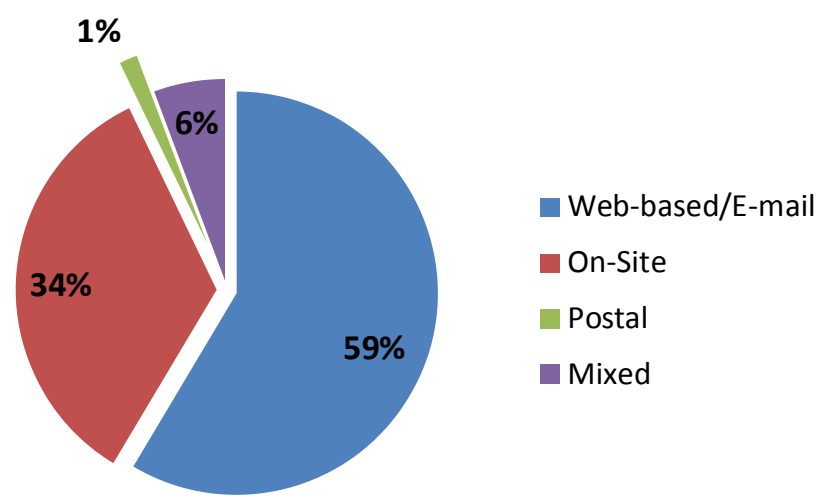

Figure 4. Data collection methodology

\subsubsection{Major theories, models and frameworks}

The 71 reviewed articles revealed the use of 28 different theories, models and frameworks, mainly from the technology adoption and social and psychological adoption paradigms (Appendix 1). The technology adoption model (TAM) was the most-used model, appearing in $33 \%$ of the studies (24 of the 71 studies). The TAM model investigates the impact of technology on user behavior, using two key constructs: perceived usefulness (PU) and perceived ease of use (PEOU). The identified weaknesses of the TAM model in predicting technology adoption at the individual level required that some studies combine the theory with other models (Casaló,et al., 2011; Jarvelainen, 2007) and extend the theory by adding other constructs (Ayeh et al., 2013; Herrero \& Martin, 2012; Morosan \& Jeong, 2008). The theory of planned behavior (TBP) was used in 10 studies (14\%) and the unified theory of acceptance and use of technology (UTAUT) was used in five studies (7\%); the theory of reasoned action (TRA) was used in four (5\%), while the elaboration likelihood model (ELM) was used in three (4\%). Some studies combined as many as four models; TRA, TPB, TAM 
and IDT (Amaro \& Duarte, 2015), while others combined three models (Al-hawari \& Mouakket, 2012; Casaló et al., 2010; Kim, et al., 2012; Lu et al., 2015).

\subsubsection{Major antecedents/constructs}

The most commonly used antecedents were those derived from the TAM model: PU and PEOU. PU implies that the user believes the technology will improve his/her performance, while PEOU implies that the user believes using the technology will be free from effort. The analyses of the tested relationships between PU and behavioral intentions reveal 15 tested relationships, and only one was rejected, while PEOU had 11 tested relationships with behavioral intention, and only 6 were accepted. To underscore the importance of satisfaction as an antecedent of intention, $\mathrm{Ku} \&$ Chen (2015) found a positive relationship between website design quality and satisfaction, which leads to continued usage intention. Additionally, service quality is important for predicting customer satisfaction and purchase intention; thus, while the TAM explicitly explains intentions, it should be expanded to incorporate satisfaction in the online context (Hsu et al., 2012). The dependent variables were attitude, behavioral intentions and usage. Attitude was tested in 17 studies to predict behavioral intentions, and all were supported. Similarly, only one study used attitude to predict use behavior, and it was accepted. Approximately 12 studies used both PU and PEOU to predict attitude, and all were accepted.

\subsection{Domain-specific findings}

This section will summarize the publications in each of the three domains. Although some constructs were the same in each of the three classifications, their contextual definitions differ. Consequently, this section will define the constructs used in the contexts of the three domains.

\subsubsection{Consumer adoption of web-based services in tourism (CAWST)}

CAWST covers the services consumers derive from tourism or hospitality organizations' websites. Generally, this domain classification focuses on these websites' influence on adoption. Out of the 71 reviewed studies, $57 \%$ (40 of 70) of the studies were published under this domain; 11 studies investigated tourism and hospitality websites' influence on destination image and destination choice (e.g., Chow \& Murphy, 2011; Hosany \& Prayag, 2013; Lee, 2009). Similarly, 13 studies investigated the influence of website design and quality on online booking and reservation (e.g., Chen, 2007; Kamarulzaman, 2007; Kucukusta et al., 2015). Additionally, trust, security and privacy were found to influence online booking and payment for tourism and hospitality products (Jarvelainen, 2007; Kim et al., 2006; Kim et al., 2013), as personal innovativeness influenced the purchase of tourism products on tourism websites (Lee et al., 2007). In line with Webster \& Watson (2002), Table 1 contains the antecedents, definitions, and frequency (the number of times used in the domain) and the authors who applied them in their studies.

Table 1. Factors associated with CAWST

\begin{tabular}{|c|c|c|c|}
\hline Construct & Definition & $\begin{array}{c}\text { Frequ } \\
\text { ency }\end{array}$ & Author(s) \\
\hline $\begin{array}{l}\text { Website design } \\
\text { quality }\end{array}$ & $\begin{array}{l}\text { The technological aspects of a } \\
\text { website, such as navigation, } \\
\text { appearance, and layout }\end{array}$ & 2 & $\begin{array}{l}\text { Ku \& Chen, 2015; Wen, } \\
2012\end{array}$ \\
\hline
\end{tabular}

Website service The efficiency and ease with $\quad 1 \quad \mathrm{Ku} \&$ Chen, 2015 


\author{
quality \\ Information \\ quality
}

Interactivity

Complexity

Navigability

Satisfaction

Perceived

enjoyment

Perceived

Compatibility

Transaction security

Trust which a consumer completes a task using a website

The reliability, currency, relevancy, completeness and accuracy of information on a website facilitating customers' decision making

The capacity for bidirectional contact and communication between the user and the supplier (website)

The degree to which purchasing travel online is perceived to be difficult

The level of ease/difficulty in moving throughout the website

Perceived degree of contentment with regard to a customer's prior purchase experience with a given electronic commerce firm

Consumers' perceptions regarding 3 the potential entertainment of internet shopping

The extent to which consumers believe that purchasing travel online fits/matches their lifestyle, needs, and shopping preference

Consists of guarantees and warranties, the discretionary use of private information, the clarity of refund policies, and the risk-free nature of online transactions

An attitude of confident expectation in an online situation of risk that one's vulnerabilities will not be exploited
Chung et al., 2015; Lin, 2010; Escobar-Rodriguez et al. 2013; Hsu et al., 2012; Wong \& Law, 2005

Ku \& Chen, 2015;

Herrero \& Martin, 2012

Amaro \& Duarte, 2015; Chen, 2007;

Herrero \& Martin, 2012

Bai et al., 2008; Chen \& Kao, 2010; Chung et al., 2015; Hosany \& Prayag, 2013; Hsu et al., 2012; Kim et al., 2006; Ku \& Chen, 2015; Lee, 2009; Luque-Martinez et al., 2007

Huang et al. 2013; Ku \& Chen, 2015; Sahli \& Legoherel, 2015;

Amaro \& Duarte, 2015; Chen, 2007; Sahli \& Legoherel, 2015

Escobar-Rodriguez et al., 2013; Kim et al., 2013; Kim et al., 2006; Ryan \& Rao, 2008

Al-hawari \& Mouakket, 2012; Amaro \& Duarte, 2015; Escobar-Rodriguez et al., 2013;

Kamarulzaman, 2007; Kim et al., 2009; Kim et al., 2013; Munoz-Leiva et al., 2012; Nunkoo \& 
Ramkisson, 2013; Sahli

\& Legoherel, 2015; Wen, 2012

Functionality
The clarity of search-related words, the usefulness of help functions, the level of technology on websites, and the overall operational efficiency in making online purchase decisions
5

Bai et al., 2008;

Kaplanidou \& Vogt, 2006; Kim et al., 2013; Lin, 2010; Ryan \& Rao, 2008

\subsubsection{Consumer adoption of social media in tourism (CASMT)}

CASMT covers studies on social media's influence on intentions to travel. Of the 71 studies, $22(31 \%)$ were published under this domain. Among social media platforms, blogs dominated research themes (Chen et al., 2014; Wang, 2011; Wang, 2012). Theories, frameworks and models used in this domain included TAM (Casaló et al., 2010; Lin, 2007) and an extension of TAM (Ayeh et al., 2013), TPB (Jalilvand \& Samiei, 2012), TRA (Hsiao et al., 2013), ELM (Filieri \& McLeay, 2013), and flow (Wu \& Chang, 2005; Ku, 2011). Some had a combination of models or theories: ELM and TPB (Wang, 2015), TPB, TAM and SIT (Casaló et al., 2010). Additionally, a majority of the studies built their conceptual frameworks on the electronic word-of-mouth (e-WOM) theory, with some extensions and modifications (Sparks \& Browning, 2011; Jalilvand et al. 2012; Zhao et al., 2015; Wang, 2011). Other antecedents are shown in Table 2.

Table 2. Factors associated with CASMT

\begin{tabular}{|c|c|c|c|}
\hline Construct & Definition & $\begin{array}{c}\text { Frequ } \\
\text { ency }\end{array}$ & Author(s) \\
\hline $\begin{array}{l}\text { Information } \\
\text { accuracy }\end{array}$ & $\begin{array}{l}\text { The correctness in the mapping of } \\
\text { stored information to the } \\
\text { appropriate state in the real world } \\
\text { that the information represents }\end{array}$ & 1 & Filieri \& McLeay, 2013 \\
\hline $\begin{array}{l}\text { Information } \\
\text { relevance }\end{array}$ & $\begin{array}{l}\text { The extent to which a review is } \\
\text { applicable and helpful for a task at } \\
\text { hand and depends on different } \\
\text { customer needs in specific } \\
\text { situations }\end{array}$ & 1 & Filieri \& McLeay, 2013 \\
\hline $\begin{array}{l}\text { Information } \\
\text { reliability }\end{array}$ & $\begin{array}{l}\text { The extent to which information } \\
\text { on social media is perceived to be } \\
\text { credible }\end{array}$ & & Chung \& Koo, 2015 \\
\hline Valence of reviews & $\begin{array}{l}\text { Positively or negatively framed } \\
\text { reviews }\end{array}$ & 2 & $\begin{array}{l}\text { Book et al., 2015; Sparks } \\
\text { \& Browning, } 2011\end{array}$ \\
\hline Trustworthiness & $\begin{array}{l}\text { The degree of confidence in the } \\
\text { communicator's intent to } \\
\text { communicate the assertions he/she } \\
\text { considers most valid }\end{array}$ & 2 & $\begin{array}{l}\text { Ayeh et al., 2013; Ayeh, } \\
\text { et al., } 2013\end{array}$ \\
\hline
\end{tabular}




\begin{tabular}{|c|c|c|c|}
\hline Homophily & $\begin{array}{l}\text { People's perceptions of others' } \\
\text { similarity to themselves in terms } \\
\text { of personal characteristics }\end{array}$ & 1 & Ayeh et al., 2013 \\
\hline Flow: & $\begin{array}{l}\text { A state of the most enjoyable } \\
\text { experience possible when a person } \\
\text { is unconsciously engaged in an } \\
\text { activity such that he or she } \\
\text { becomes so absorbed that he or } \\
\text { she loses the sense of self }\end{array}$ & & $\begin{array}{l}\mathrm{Ku}, 2011 ; \text { Wu \& Chang, } \\
2005\end{array}$ \\
\hline $\begin{array}{l}\text { Perceived } \\
\text { enjoyment }\end{array}$ & $\begin{array}{l}\text { The degree of playfulness } \\
\text { experienced while using social } \\
\text { media for travel }\end{array}$ & 5 & $\begin{array}{l}\text { Ayeh et al., 2013; Chen et } \\
\text { al., 2014; Chung \& } \\
\text { Koo,2015; Ku, 2011; Wu } \\
\text { \& Chang, 2005 }\end{array}$ \\
\hline Source credibility & $\begin{array}{l}\text { The believability of some } \\
\text { information or its source on social } \\
\text { media }\end{array}$ & & $\begin{array}{l}\text { Ayeh et al., 2013; Wang, } \\
2015\end{array}$ \\
\hline Reviewer expertise & $\begin{array}{l}\text { The extent to which the reviewer } \\
\text { is perceived as being capable of } \\
\text { providing correct information }\end{array}$ & 2 & $\begin{array}{l}\text { Ayeh et al., 2013; Zhao et } \\
\text { al., } 2015\end{array}$ \\
\hline Content novelty & $\begin{array}{l}\text { The degree to which the } \\
\text { information within a traveler's } \\
\text { blog is perceived to be new }\end{array}$ & 1 & Chen et al., 2014 \\
\hline
\end{tabular}

\subsubsection{Consumer adoption of mobile information system in tourism (CAMIST)}

CAMIST represents studies dealing with consumers' adoption of mobile information systems in tourism. The ubiquity of smartphones and tablets and the corresponding increase in mobile application development are expected to greatly impact the tourism industry. As an information-intensive sector, information interchange is very crucial for both service providers and tourists. In spite of the importance of these emerging tools for the tourism industry, research on CAMIST in tourism remains scarce. Specifically, 11\% (8 out of 71) of the reviewed articles were in this domain. The first study in this stream was conducted in 2008 (Kim et al., 2008), with 2015 publishing the highest number of studies (see appendix 1). Two studies used the UTAUT model (Lai, 2015; No \& Kim, 2014), one study used TAM (Kim et al., 2008), and another used TAM in combination with IDT and SCT (Lu et al., 2015). Others used ELM, DTPB, GT, NT and UDT (see appendix 1). The antecedents and authors who applied these models in this domain are shown in Table 3. 
Table 3. Factors associated with CAMIST

\begin{tabular}{|c|c|c|c|}
\hline Construct & Definition & $\begin{array}{c}\text { Frequ } \\
\text { ency }\end{array}$ & Author(s) \\
\hline Involvement & $\begin{array}{l}\text { The degree of interest in the } \\
\text { mobile device or app }\end{array}$ & 2 & $\begin{array}{l}\text { Chang et al., 2016; Kim } \\
\text { et al., } 2015\end{array}$ \\
\hline Use context & $\begin{array}{l}\text { Personal and environmental } \\
\text { conditions that influence the use of } \\
\text { mobile devices in purchasing or } \\
\text { reserving tourism products or } \\
\text { services }\end{array}$ & 1 & Kim et al., 2015 \\
\hline Informativeness & $\begin{array}{l}\text { The degree to which the mobile } \\
\text { device or app contains relevant, } \\
\text { timely, up-to-date and correct } \\
\text { informative }\end{array}$ & 1 & I : 3015 \\
\hline $\begin{array}{l}\text { Mobile self- } \\
\text { efficiency }\end{array}$ & $\begin{array}{l}\text { Degree of ability by which } \\
\text { consumers consider themselves } \\
\text { able to independently use mobile } \\
\text { device or tourism apps in order to } \\
\text { obtain information }\end{array}$ & & Chang et al., 2016 \\
\hline Information gain & $\begin{array}{l}\text { Extrinsic pull motivations are } \\
\text { connected to external, situational, } \\
\text { or cognitive aspects }\end{array}$ & 1 & Chung et al., 2014 \\
\hline Entertainment & $\begin{array}{l}\text { Enjoyment, fun, pleasure and } \\
\text { excitement that tourists experience } \\
\text { when using mobile device or } \\
\text { tourism apps }\end{array}$ & 1 & Lai, 2015; Lu et al., 2015 \\
\hline
\end{tabular}

\section{Discussion/Implications}

The aim of this study was to provide a review of consumers' adoption of e-tourism; antecedents of e-tourism adoption; synthesis of the theories, models and frameworks and a classification based on a grouping of relevant studies. Consequently, the 71 reviewed articles were classified into studies on CAWST, CASMT and CAMIST.

CAWST depended on website attributes and consumers' personal characteristics. Consumers consider security, navigation functionality and information quality as important website attributes for online tourism transactions (Kim et al., 2013; Chung et. al. 2015). Wen (2012) found that quality of website design has had a positive influence on consumers' attitude towards online purchases of travel and tourism products. Particularly, consumers' adoption of a particular website for hotel bookings was influenced by the information available on the website, security, and content-motivating visuals (Wong \& Law, 2005; Kim et al., 2006; Ryan \& Rao, 2008). Incorporating privacy assurance on travel websites increases the perceived usefulness of services and decreases customers' privacy concerns, thus influencing adoption (Lee \& Cranage, 2011). In fact, consumers' emotional involvement, attitude, innovativeness and flow are important personal characteristics for the purchase of travel 
online (Kim et al., 2012; Huang et al. 2013). However, consumers of low-cost airlines who purchase tickets online are influenced mostly by their trust and habits in using such websites (Escobar-Rodriguez \& Carvajal-Trujillo, 2013).

CASMT is influenced by pre-trip, during-trip and post-trip behaviors. Additionally, consumers' personal characteristics, the characteristics of the source and the elements of the content influence social media content use for travel information search. Thus, experienced, involved and innovative consumers are more predisposed to use social media for travel information search $(\mathrm{Ku}, 2011)$. Those who belong to the same network and those outside the network can access shared content; thus, source credibility (expertise and trustworthiness) becomes an important determinant of content believability (Ayeh et al., 2013). Furthermore, novelty, understandability and interesting elements in a travel blog influence adoption (Chen et al., 2014). Advice from the online community is more influential than marketer-generated content; consequently, consumers are influenced most by negative reviews, especially when those reviews are negatively valenced (Sparks \& Browning, 2011).

CAMIST comprises mobile devices and mobile applications (Shaikh \& Karjaluoto, 2015). Perceived usefulness, ease of use and informativeness will allow mobile technologies to continue to grow among tourism consumers (Chang et al., 2016), even though these factors are not seen to pose an immediate threat to traditional personal computers (PCs) (Okazaki \& Hirose, 2009). In terms of personal factors, trip and technology experiences are important determinants; thus, frequent travelers have a higher adoption rate of CAMIST (Kim et al., 2008). Consumers show more satisfaction with mobile applications that contain more travelrelated information (No \& Kim, 2014), which are, thus, more gratifying than the PC internet (Okazaki \& Hirose, 2009).

\subsection{Contributions of the study}

First, the identification of three domains that influence consumers' adoption of e-tourism CAWST, CASMT and CAMIST - indicates that research in these areas is uneven. While there is preponderance of research on CAWST and CASMT, there is an evident dearth of research on CAMIST. Increasing mobile devices and applications are emerging, and tourism and hospitality service providers are increasingly deploying these technologies to ensure consumer satisfaction. Therefore, studies on the factors that influence the adoption of these mobile technologies are essential. The growth of mobile technology use across different groups indicates that social and cultural factors play a role in their adoption. Consequently, Lu et al. (2015) suggested investigating potential differences in user needs from travel apps across different groupings and cultures.

Second, this study further reveals that the models used in the majority of the studies were the TAM, TPB, UTAUT and TRA. Some studies used the above models according to their original postulations, while others modified or extended them (Huang et al., 2013; Kim et al., 2009). Additionally, several studies borrowed constructs from established models and frameworks in the social and psychological disciplines (Chung et al., 2015; Filieri \& McLeay, 2013). Furthermore, because studies on CASMT are rooted in the e-WOM literature, the majority of the studies adopted e-WOM as a conceptual model but borrowed constructs mainly from TAM. Similarly, the most-tested paths were drawn from the TAM constructs, which included the PU, PEOU, Attitude (ATT) and Behavioral intention (BI). For instance, effect of ATT on BI was tested in 17 studies, which all were accepted; PU on BI were tested in 15 studies, and 14 (93\%) were accepted; and PEOU on BI was tested by 11 
studies, and 6 (54\%) were accepted. The path analysis of the proposed UTAUT constructs and their acceptance rates were equally high.

Third, the reviewed studies show that the influence of website design quality on destination image perception and choice featured prominently in the CAWST classification. Additionally, security, privacy and trust were highlighted as important considerations in consumers' booking, reservation and payment for tourism services on tourism and hospitality firms' websites. The majority of the studies on the CASMT classification focused on adoption via Facebook, Twitter and blogs. However, many other social media platforms that are very important in the tourism and travel industries, such as TripAdvisor, YouTube, Lonely Planet, Flickr, Delicious and Digg, have received scant attention.

Fourth, the reviewed studies offered many practical implications that can aid managers in the tourism and hospitality sector to strategically position their services in the emerging information technology and systems era. In this vein, for managers of the tourism and hospitality services to attract and retain customers, they must understand the role of website design, social media and mobile technology as e-tourism platforms. Specifically, $\mathrm{Ku}$ and Chen (2015) suggest that managers should ensure that e-tourism websites incorporate features that ensure quick navigation, interaction and creativity in packaging information content enhanced through audio and video clips, which have the potential to enhance tourists' perception of reality. Destination image perception and choice constitute an important research stream in tourism studies. The emergence of the internet has helped to better inform tourists about destinations. For instance, Sparks and Pan (2009) argue that most Chinese tourists obtain information on possible destinations online. It is therefore imperative for managers to incorporate features on e-tourism websites that enhance a positive perception of destination image.

Finally, in order to ensure effective participation in firm-hosted online travel communities, Casaló et al. (2010) suggest that firms promote group cohesion and communication among community members by encouraging shared identity; this can be achieved by organizing meetings among the community members. In this way, new members who are likely to visit the destination can be introduced to the community. Finally, Chang et al. (2016) posit that managers should develop mobile applications that are contextually customizable in relation to the needs of the tourist.

\subsection{Limitations and future research directions}

The study is not without limitations. First, a major limitation of the study is that it was based on quantitative studies only. Reviews that incorporate both qualitative and quantitative studies are more comprehensive. Another limitation of this study is that it did not incorporate other sources, such as conference proceedings, book chapters, and conceptual papers, which might have impacted the study differently. Additionally, the literature search was conducted from October 2015 to January 2016; thus, only one paper was included for 2016. Other publications beyond January 2016 are obviously not included in the study. Finally, while the literature search was extensive, we may have missed some publications within the period of inclusion.

One outstanding finding of the study is the scant research on CAMIST, which includes the adoption and use of mobile devices and applications. Travel information is dynamic and requires context-specific mobile applications; therefore, more research should be focused on the factors influencing the adoption of these mobile technologies. Second, Facebook and 
blogs were the most commonly studied platforms in the CASMT domain. Important platforms such as YouTube, Delicious, Digg, and Lonely Planet are also very important for travel and tourism; further research should incorporate these networks into the literature on social media in tourism. Finally, the reviewed studies found an uneven geographical spread of studies. While many studies have been conducted in Asia (Taiwan and China), the USA, and most parts of Europe, some emerging markets such as India and Africa, are largely absent, ignoring the increase in internet subscriptions in these emerging markets. Future research on these emerging markets will likely provide valuable insights.

\section{References}

Ajzen, I. (1991). Theory of planned behavior. Organizational Behavior and Human Decision Processes, 50(2), 179-211.

Amaro, S. \& Duarte, P. (2015). An integrative model of consumers' intentions to purchase travel online. Tourism Management, 46, 64-79.

Al-hawari, M.A. \& Mouakket, S. (2012). Do offline factors trigger customers' appetite for online continual usage?: A study of online reservation in the airline industry. Asia Pacific Journal of Marketing and Logistics, 24(4) 640-645.

Ayeh, J.K., Au, N. \& Law, R. (2013). "Do We Believe in TripAdvisor?" Examining Credibility Perceptions and Online Travelers' Attitude toward Using User-Generated Content. Journal of Travel Research, XX(X) 1-16.

Ayeh, J.K., Au, N. \& Law, R. (2013). Predicting the intention to use consumer-generated media for travel planning. Tourism Management, 35, 132-143.

Bai, B., Law, R. \& Wen, I. (2008). The impact of website quality on customer satisfaction and purchase intentions: Evidence from Chinese online visitors. International Journal of Hospitality Management, 27,391-402.

Baron, S., Warnaby, G., \& Hunter-Jones, P. (2014). Service (s) marketing research: developments and directions. International Journal of Management Reviews, 16(2), 150171.

Book, L.A., Tanford, S. Montgomery, R. \& Love C. (2015). Online traveler reviews as social influence: price is no longer king. Journal of Hospitality \& Tourism Research, $\mathrm{xx}(\mathrm{x}) 1-$ 31.

Buhalis, D. (1996). Information technologie as a stategic tool for tourism. The Tourist Review, 51(2), 34-36.

Buhalis, D. (2000). Tourism and information technologies: Past, present and future. Tourism Recreation Research, 25(1), 41-58.

Buhalis, D. \& Deimezi, O. (2004). E-tourism developments in Greece: Information communication technologies adoption for the strategic management of the Greek tourism industry. Tourism and Hospitality Research, 5(2), 103-130. 
Buhalis, D., \& Law, R. (2008). Progress in information technology and tourism management: 20 years on and 10 years after the Internet-The state of eTourism research. Tourism Management, 29(4), 609-623.

Buhalis, D., \& Jun, S. H. (2011). E-tourism. Contemporary tourism reviews, 01-38.

Cardoso, J., \& Lange, C. (2007). A framework for assessing strategies and technologies for dynamic packaging applications in e-tourism. Information Technology \& Tourism, 9(1), $27-44$.

Casaló, L.V., Flavian, C. \& Guinaliu, M. (2010). Determinants of the intention to participate in firm-hosted online travel communities and effects on consumer behavioural intentions. Tourism Management, 31, 898-911.

Casaló, L.V., Flavian, C. \& Guinaliu, M. (2011). Understanding the intention to follow the advice obtained in an online travel community. Computers in Human Behaviour, 27, 622-633.

Chang, I. Chou, P. Yeh, K. \& Tseng, H. (2016). Factors influencing Chinese tourists' intention to use the Taiwan Medical App. Telematics \& Informatics, 33, 401-409.

Chen, F.C.Y. (2007). Passenger use intentions for electronic tickets on international flights. Journal of Air Transport Management, 13, 110-115.

Chen, C. \& Kao, Y. (2010). Relationships between process quality, outcome quality, satisfaction, and behavioural intentions for online travel agencies - evidence from Taiwan. The Service Industries Journals, 30(12) 2081-2092.

Chen, Y., Shang, R. \& Li, M. (2014). The effect of perceived relevance of travel blogs' content on the behavioural intention to visit a tourist destination. Computers in Human Behaviour, 30, 787-799.

Cheung, C.M.K. \& Thadani, D.R. (2012). The impact of electronic word-of-mouth communication: A literature analysis and integrative model. Decision Support Systems, $54,461-470$.

Chow, I. \& Murphy, P. (2011). Predicting Intended and Actual Travel Behaviours: An Examination of Chinese Outbound Tourists to Australia. Journal of Travel \& Tourism Marketing, 28, 318-330.

Chung, N. \& Koo, C. (2015). The use of social media in travel information search. Telematics and Informatics 32(2), 215-229. doi:10.1016/j.tele.2014.08.005.

Chung, N., Koo, C. \& Kim, K. (2014). Extrinsic and intrinsic motivation for using a booth recommender system service on exhibition attendees' unplanned visit behaviour. Computers in Human Behaviour, 30, 59-68.

Chung, N., Lee, H., Lee, S.J. \& Koo, C. (2015). The influence of tourism website on tourists' behavior to determine destination selection: a case study of creative economy in Korea. Technology Forecasting and Social Change, 96, 130-143. 
Davis, F.D. (1989). Perceived usefulness, perceived ease of use, and user acceptance of information technology. MIS Quarterly, 319-340.

Escobar-Rodriguez, T. \& Carvajal-Trujillo, E. (2013). Online drivers of consumer purchase of website airline tickets. Journal of Air Transport Management, 32, 58-64.

Filieri, R. \& McLeay, F. (2013). E-WOM and accommodation: An analysis of the factors that influence travelers' adoption of information from online reviews. Journal of Travel Research, 53(1) 44-57.

Fishbein, M. and Ajzen, I. (1975). Belief, Attitude, Intention and Behavior: An Introduction to Theory and Research, Addison-Wesley, Reading: MA

Fodor, O., \& Werthner, H. (2005). Harmonise: A step toward an interoperable e-tourism marketplace. International Journal of Electronic Commerce, 9(2), 11-39.

Frew, A.J. (2000). Information and Communications Technology Research in the Travel and Tourism Domain: Perspective and Direction. Journal of Travel Research, 39, 136145.

GoodWorkLabs (2016). http://www.goodworklabs.com/how-mobile-app-benefits-travel-andtourism-industryl. Accessed March 23, 2016.

García-Crespo, A., Chamizo, J., Rivera, I., Mencke, M., Colomo-Palacios, R., \& GómezBerbís, J. M. (2009). SPETA: Social pervasive e-Tourism advisor. Telematics and Informatics, 26(3), 306-315.

Herrero, A. \& Martin, H.S. (2012). Developing and testing a global model to explain the adoption of websites by users in rural tourism accommodations. International Journal of Hospitality Management, 31, 1178-1186.

Ho, C. \& Lee, P. (2015). Are blogs still effective to maintain customer relationships? An empirical study on the travel industry. Journal of Hospitality and Tourism Technology, 6(1) $5-25$.

Hosany, S. \& Prayag, G. (2013). Patterns of tourists' emotional responses, satisfaction, and intention to recommend. Journal of Business Research, 66, 730-737.

Hsiao, K., Lu, H. \& Lan, W. (2013). The influence of the components of storytelling blogs on readers' travel intentions. Internet Research, 23(2) 160-182.

Hsu, C., Chang, K. \& Chen, M. (2012). The impact of website quality on customer satisfaction and purchase intention: perceived playfulness and perceived flow as mediators. Information Systems \& E-Business Management, 10, 549-570.

Huang, Y., Backman, S.J., Backman, K.F. \& Moore, D. (2013). Exploring user acceptance of 3D virtual worlds in travel and tourism marketing. Tourism Management, 36, 490-501. 
King, R.A., Racherla, P. \& Bush, V.D. (2014). What we know and don't know about online word-of-mouth: A review and synthesis of literature. Journal of Interactive Marketing, $28,167-183$.

Jalilvand, M.R., Samiei, N. (2012). The impact of electronic word of mouth on a tourism destination choice. Internet Research, 22(5) 591-612.

Jalilvand, M.R., Samiei, N., Dini, B. \& Manzari, P.Y. (2012). Examining the structural relationships of electronic word of mouth, destination image, tourist attitude toward destination and travel intention: An integrated approach. Journal of Destination Marketing \& Management, 1, 134-143.

Jarvelainen, J. (2007). Online Purchase Intentions: An Empirical Testing of Multiple-Theory Model. Journal of Organisational Computing and Electronic Commerce, 17(1), 53-74.

Kamarulzaman, Y. (2007). Adoption of travel e-shopping in the UK. International Journal of Retail \& Distribution Management, 35(9), 703-719.

Kaplanidou, K. \& Vogt, C. (2006). A Structural Analysis of Destination Travel Intentions as a Function of Web Site Features. Journal of Travel Research, 45, 204-216.

Kim, M.J., Chung, N., Lee, C. \& Preis, M.W. (2015). Motivations and Use Context in Mobile Tourism Shopping: Applying Contingency and Task-Technology Fit Theories. International Journal of Tourism Research, 17, 13-24.

Kim, H., Kim, T. \& Shin, S.W. (2009). Modelling roles of subjective norms and eTrust in customers' acceptance of airline B2C eCommerce websites. Tourism Management, 30, 266-277.

Kim, M., Lee, C. \& Chung, N. (2013). Investigating the role of trust and gender in online tourism shopping in South Korea. Journal of Hospitality \& Tourism Research, 37(3) $377-401$.

Kim, M., Lee, M.J., Lee, C. \& Song, H. (2012). Does Gender Affect Korean Tourist's Overseas Travel? Applying the Model of Goal-Directed Behaviour. Asia Pacific Journal of Tourism Research, 17, 509-533.

Kim, W.G., Ma, X. \& Kim, D.J. (2006). Determinants of Chinese hotel customers' esatisfaction and purchase intentions. Tourism Management, 27, 890-900.

Kim, D., Park, J. \& Morrison, M. (2008). A model of traveller acceptance of mobile technology. International Journal of Tourism Research, 10, 393-407.

$\mathrm{Ku}$, E.C.S. (2011). Recommendations from a virtual community as a catalytic agent of travel decisions. Internet Research, 21(3) 282-303.

Ku, E.C.S. \& Chen, C. (2015). Cultivating traveler's revisit intention to e-tourism service: the moderating effect of website interactivity. Behaviour \& Information Technology, 34(5) 465-478. 
Kucukusta, D., Law, R., Besbes, A. \& Legoherel, P. (2015). Re-examining perceived usefulness and ease of use in online booking: The case of Hong Kong online users. International Journal of Contemporary Hospitality Management, 27(2) 185-198.

Lai, I.K.W. (2015). Travelers' acceptance of an App-based mobile tour guide. Journal of Hospitality \& Tourism Research, 39(3), 401-432.

Law, R., Leung, R., Buhalis, D. (2009). Information Technology Application in Hospitality and Tourism: A Review of Publication from 2005-2007. Journal of Travel \& Tourism Marketing, 26, 599-623.

Law, R., Qi, S. \& Buhalis, D. (2010). Progress in tourism management: A review of website evaluation in tourism research. Tourism Management, 31, 297-313.

Law, R., Buhalis, D. \& Cobanoglu, C. (2014). Progress on information and communication technologies in hospitality and tourism, International Journal of Contemporary Hospitality Management, 26(5) 727-750.

Lee, T.H. (2009). A structural model to examine how destination image, attitude, and motivation affect the future behavior of tourists. Leisure Sciences, 31(3) 215-236.

Lee, C.H. \& Cranage, D.A. (2011). Personalization - privacy paradox: The effects of personalization and privacy assurance on customer responses to travel Web sites. Tourism Management, 32, 987-994.

Lee, H.Y., Qu, H. \& Kim, Y.S. (2007). A study of the impact of personal innovativeness on online travel shopping behavior - A case study of Korean travelers. Tourism Management, 28, 886-897.

Leung, R., Law, R. (2007). Information Technology Publications in Leading Tourism Journals: A Study of 1985-2004. Information Technology and Tourism, 9(2) 133-144.

Leung, D., Law, R., Hoof, H.V. \& Buhalis, D. (2013). Social Media in Tourism and Hospitality: A Literature Review. Journal of Travel \& Tourism Marketing, 30, 3-22.

Leung, X.Y., Xue, L. \& Bai, B. (2015). Internet marketing research in hospitality and tourism: a review and journal preferences. International Journal of Contemporary Hospitality Management, 27(7) 1556-1572.

Lin, H. (2007). The role of online and offline features in sustaining virtual communities: an empirical study. Internet Research, 17(2), 119-138.

Lin, C. (2010). Examining e-travel sites: an empirical study in Taiwan. Online Information Review, 34(2) 205-228

Liu, J.N.K. \& Zhang, E.Y. (2014). An investigation of factors affecting customer selection of online hotel booking channels. International Journal of Hospitality Management, 39, 7183. 
Lu, J., Mao, Z., Wang, M. \& Hu, L. (2015). Goodbye maps, hello apps? Exploring the influential determinants of travel app adoption. Current Issues in Tourism, 18(11), 10591079. DOI: $10.1080 / 13683500.2015 .1043248$

Lu, W. \& Stepchenkova, S. (2015). User-generated content as a research mode in tourism and hospitality applications: Topics, methods, and software. Journal of Hospitality Marketing \& Management, 24(2), 119-154.

Luque-Martinez, T., Castaneda-Garcia, J.A., Frias-Jamilena, D.M., Munoz-Leiva, F. \& Rodriguez-Molina, M.A. (2007). Determinants of the Use of the Internet as a Tourist Information Source. The Service Industries Journal, 27(7), 881-891.

Martin, H.S. \& Herrero, A. (2012). Influence of the user's psychological factors on the online purchase intention in rural tourism: Integrating innovativeness to the UTAUT framework. Tourism Management, 33, 341-350.

Morosan, C. \& Jeong, M. (2008). Users' perceptions of two types of hotel reservation Web sites. International Journal of Hospitality Management, 27, 284-292.

Munoz-Leiva, F., Hernandez-Mendez, J. \& Sanchez-Fernandez, J. (2012). Generalizing user behavior in online travel sites through the Travel 2.0 website acceptance model. Online Information Review, 36(6) 879-902.

No, E. \& Kim, J.K. (2014). Determination of the adoption for travel Information on Smartphone. International Journal of Tourism Research, 16, 534-545.

Nunkoo, R. \& Ramkisson, H. (2013). Travelers' e-purchase intent on tourism products and services. Journal of Hospitality Marketing \& Management, 22, 505-529.

Okazaki, S. \& Hirose, M. (2009). Does gender affect media choice in travel information search? On the use of mobile internet. Tourism Management, 30, 794-804.

Okoli, C. \& Schabram, K. (2010). A guide to conducting a systematic literature review of information systems research. Sprouts work. Pap. Information Systems 10, 26.

Parra-Lopez, E., Bulchand-Gidumal, J., Gutierrez-Tano, D. \& Diaz-Armas, R. (2011). Intentions to use social media in organisation and taking vacation trips. Computers in Human Behaviour, 27, 640-654.

Pesonen, A J. (2013). Information and communications technology and market segmentation in tourism: a review. Tourism Review, 68(2), 14-30.

Rasty, F., Chou, C. \& Feiz, D. (2013). The Impact of Internet Travel Advertising Design, Tourist's Attitude, and Internet Travel Advertising Effect on Tourist's Purchase Intention: The moderating role of involvement. Journal of Travel \& Tourism Marketing, 30, 482-496.

Ryan, C. \& Rao, U. (2008). Holiday Users of the Internet - Ease of Use, Functionality and Novelty. International Journal of Tourism Research, 10, 329-339. 
Sebastia, L., Garcia, I., Onaindia, E., \& Guzman, C. (2009). e-Tourism: a tourist recommendation and planning application. International Journal on Artificial Intelligence Tools, 18(05), 717-738.

Sahli, A.B. \& Legoherel, P. (2015). The tourism web acceptance model: A study of intention to book tourism products online. Journal of Vacation Marketing, DOI: $10.1177 / 1356766715607589$.

Shaikh, A. A., \& Karjaluoto, H. (2015). Mobile banking adoption: A literature review. Telematics and Informatics, 32(1), 129-142.

Shaikh, A. A., \& Karjaluoto, H. (2015). Making the most of information technology \& systems usage: A literature review, framework and future research agenda. Computers in Human Behavior, 49, 541-566.

Shaikh, A. A., \& Karjaluoto, H. (2016). Mobile banking services continuous usage--case study of finland. In 2016 49th Hawaii International Conference on System Sciences (HICSS) (pp. 1497-1506). IEEE.

Singh, R. (2015). The state of Indian tourism and hospitality research: A review and analysis of journal publications. Tourism Management Perspectives, http://dx.doi.org/10.1016/j.tmp.2015.07.002

Siricharoen, W. V. (2008). Learning semantic web from e-tourism. In Agent and Multi-Agent Systems: Technologies and Applications (pp. 516-525). Springer Berlin Heidelberg.

Sparks, B.A. \& Browning, V. (2011). The impact of online reviews on hotel booking intentions and perception of trust. Tourism Management, 32, 1310-1323.

Sparks, B., \& Pan, G. W. (2009). Chinese outbound tourists: Understanding their attitudes, constraints and use of information sources. Tourism Management, 30(4), 483-494.

Sparks, B.A., Perkins, H.E. \& Buckley, R. (2013). Online travel reviews as persuasive communication: The effects of content type, source, and certification logos on consumer behavior. Tourism Management, 39, 1-9.

Statistica (2016). http://www.statista.com/statistics/238852/online-travel-bookingsworldwide/

TripAdvisor (2016). https://www.tripadvisor.com/PressCenter-c4-Fact_Sheet.html. Accessed March 23, 2016.

Tsao, W., Hsieh, M., Shih, L. \& Lin, T.M.Y. (2015). Compliance with eWOM: the influence of hotel reviews on booking intention from the perspective of consumer conformity. International Journal of Hospitality Management 46, 99-111. doi:10.1016/j.ijhm.2015.01.008.

Venkatesh, V., Morris, M.G., Davis, G.B. and Davis, F.d. (2003). User acceptance of information technology: toward a unified view. MIS Quarterly, 425-478. 
Wang, H. (2011). Exploring the factors of gastronomy blogs influencing readers' intention to taste. International Journal of Hospitality Management, 30, 503-514.

Wang, H. (2012). Investigating the determinants of travel blogs influencing readers' intention to travel. The Service Industries Journal, 32(2) 231-255.

Wang, P. (2015). Exploring the influence of electronic word-of-mouth on tourist's visit intention. Journal of Systems and Information Technology, 17(4) 381-396.

Webster, J. \& Watson, R.T. (2002). Analyzing the past to prepare for the future: writing a. MIS Quarterly 26(2), 13-23.

Wen, I. (2012). An empirical study of an online travel purchase intention model. Journal of Travel and Tourism Marketing, 29(1) 18-39.

Wen, I. (2013). Online Shopping of Travel Products: A Study of Influence of Each Dimension of travelers' Attitudes and the Impact of travelers' Online Shopping Experiences on Their Purchase Intentions. International Journal of Hospitality \& Tourism Administration, 14(3) 203-232.

Wong, J. \& Law, R. (2005). Analysing the intention to purchase on hotel websites: a study of travellers to Hong Kong. International Journal of Hospitality Management, 24, 311-329.

WTTC (2016). World Travel and Tourism Council. Available on: http://www.wttc.org/

Wu, J. \& Chang, Y. (2005). Towards understanding members' interactivity, trust, and flow in online travel community. Industrial Management \& Data Systems, 105(7), 937-954.

Wu, Y., Chiu, C., Yang, P. \& Li, C. (2011). Impact of web usability on user acceptance using tourism website. Journal of Statistics and Management Systems, 14(6) 1007-1025, DOI 10.1080/09720510.2011.10701598.

Zeng, B. \& Gerritsen, R. (2014). What do we know about social media in tourism? A review. Tourism Management Perspectives, 10, 27-36.

Zhao, X., Wang, L., Guo, X. \& Law, R. (2015). The influence of online reviews to online hotel booking intentions. International Journal of Contemporary Hospitality Management, 27(6) 1343-1364.

Zhu, D. H., Chang, Y. P., \& Luo, J. J. (2016). Understanding the influence of C2C communication on purchase decision in online communities from a perspective of information adoption model. Telematics and Informatics, 33(1), 8-16.

This work was supported by the Centre for International Mobility (CIMO), Finland [Grant Numbers:

TM-15-9930] 
Appendix 1

\begin{tabular}{|c|c|c|c|c|c|c|c|c|c|c|}
\hline \multirow[t]{2}{*}{$\mathbf{S} / \mathbf{N}$} & \multirow{2}{*}{$\begin{array}{l}\text { Author/ } \\
\text { Year }\end{array}$} & \multirow[t]{2}{*}{ Purpose } & \multirow[t]{2}{*}{ Country } & \multicolumn{3}{|c|}{ Methodology } & \multirow{2}{*}{$\begin{array}{c}\text { Independent } \\
\text { Variable(s) }\end{array}$} & \multirow{2}{*}{$\begin{array}{l}\text { Dependent } \\
\text { Variable(s) }\end{array}$} & \multirow{2}{*}{$\begin{array}{c}\text { Theory } \\
\text { /Model/ } \\
\text { Framewor } \\
\mathbf{k} \\
\end{array}$} & \multirow[b]{2}{*}{ Findings } \\
\hline & & & & $\begin{array}{c}\text { Data } \\
\text { Collection }\end{array}$ & $\begin{array}{c}\text { Sample/ } \\
\text { Unit of } \\
\text { Analysis }\end{array}$ & $\begin{array}{c}\text { Data } \\
\text { Analysis }\end{array}$ & & & & \\
\hline \multicolumn{11}{|c|}{ Consumer adoption of web-based services in tourism (CAWST) } \\
\hline 1 & Ku \& Chen (2015) & $\begin{array}{l}\text { To investigate how } \\
\text { design and service } \\
\text { quality of public tourism } \\
\text { websites affect } \\
\text { satisfaction }\end{array}$ & Taiwan & Online survey & $\begin{array}{l}256 ; \\
\text { Individuals }\end{array}$ & $\begin{array}{l}\text { Structural } \\
\text { equation } \\
\text { modelling } \\
\text { (SEM) }\end{array}$ & $\begin{array}{l}\text { Satisfaction, } \\
\text { Website Design } \\
\text { Quality } \\
\text { Enjoyment, } \\
\text { Web ervice } \\
\text { Quality. } \\
\text { Interactivity as } \\
\text { moderating } \\
\text { variable }\end{array}$ & $\begin{array}{l}\text { Continued } \\
\text { website usage } \\
\text { intention }\end{array}$ & TAM, EUS & $\begin{array}{l}\text { There is positive relationship } \\
\text { between website design quality } \\
\text { and satisfaction. Also, a tourist's } \\
\text { satisfactions positively influences } \\
\text { his continued usage intention. }\end{array}$ \\
\hline 2 & $\begin{array}{l}\text { Amaro \& Duarte } \\
(2015)\end{array}$ & $\begin{array}{l}\text { To examine factors } \\
\text { influencing purchasing } \\
\text { travel online }\end{array}$ & Portugal & Online survey & $\begin{array}{l}1,732 ; \\
\text { colleagues } \\
\text { and } \\
\text { acquaintances }\end{array}$ & SEM & $\begin{array}{l}\text { Compatibility, } \\
\text { Perceived } \\
\text { Relative } \\
\text { Advantages, } \\
\text { Attitude, } \\
\text { Complexity, } \\
\text { Perceived } \\
\text { Behavoural } \\
\text { Control, } \\
\text { Communication } \\
\text { Trust, } \\
\text { Perceived Risk } \\
\end{array}$ & $\begin{array}{l}\text { Intentions to } \\
\text { purchase travel } \\
\text { online }\end{array}$ & $\begin{array}{l}\text { TRA, TPB, } \\
\text { TAM, IDT }\end{array}$ & $\begin{array}{l}\text { Intentions to purchase travel } \\
\text { online are mostly determined } \\
\text { by attitude, compatibility and } \\
\text { perceived risk. }\end{array}$ \\
\hline 3 & $\begin{array}{l}\text { Kim, Lee \& Chung } \\
\text { (2013) }\end{array}$ & $\begin{array}{l}\text { To examine the } \\
\text { influence of trust in } \\
\text { online tourism } \\
\text { repurchase intention }\end{array}$ & $\begin{array}{l}\text { Republic of } \\
\text { Korea }\end{array}$ & Online survey & $\begin{array}{l}340, \text { potential } \\
\text { online } \\
\text { tourism } \\
\text { shoppers }\end{array}$ & SEM & $\begin{array}{l}\text { Trust, } \\
\text { Benevolence, } \\
\text { Integrity, } \\
\text { Ability, } \\
\text { Transaction } \\
\text { security, } \\
\text { Navigation } \\
\text { functionality, } \\
\text { cost } \\
\text { effectiveness }\end{array}$ & $\begin{array}{l}\text { Repurchase } \\
\text { intention }\end{array}$ & TCT & $\begin{array}{l}\text { It found that transaction security, } \\
\text { navigation functionality and cost } \\
\text { effectiveness affect trust which in } \\
\text { turn affect repurchase intention. }\end{array}$ \\
\hline 4 & $\begin{array}{l}\text { Chung, Lee, Lee \& } \\
\text { Koo (2015) }\end{array}$ & $\begin{array}{l}\text { To investigate the } \\
\text { relationship between the } \\
\text { qualities of DMO and } \\
\text { continuous usage } \\
\text { intention }\end{array}$ & $\begin{array}{l}\text { Republic of } \\
\text { Korea }\end{array}$ & Online survey & 169 ; tourists & SEM & $\begin{array}{l}\text { Destination } \\
\text { website } \\
\text { usefulness, } \\
\text { Destination } \\
\text { website } \\
\text { satisfaction, } \\
\text { Destination } \\
\text { website quality } \\
\text { confirmation }\end{array}$ & Usage Intention & ECM & $\begin{array}{l}\text { Information quality was an } \\
\text { important factor in deciding a } \\
\text { destination website. It also found } \\
\text { that the continuance to visit the } \\
\text { website influence the use of the } \\
\text { website }\end{array}$ \\
\hline
\end{tabular}




\begin{tabular}{|c|c|c|c|c|c|c|c|c|c|c|}
\hline & & & & & & & $\begin{array}{l}\text { (information } \\
\text { quality, service } \\
\text { quality, design } \\
\text { quality) }\end{array}$ & & & \\
\hline 5 & $\begin{array}{l}\text { Sahli \& Legoherel } \\
\text { (2015) }\end{array}$ & $\begin{array}{l}\text { To examine the factors } \\
\text { influencing intention to } \\
\text { book tourism online }\end{array}$ & Tunisia & $\begin{array}{l}\text { Online survey } \\
\text { (Facebook) }\end{array}$ & $\begin{array}{l}\text { 389; internet } \\
\text { users }\end{array}$ & SEM, & $\begin{array}{l}\text { Perceived } \\
\text { enjoyment, } \\
\text { Subjective } \\
\text { norms, Attitude, } \\
\text { Compatibility, } \\
\text { Perceived } \\
\text { usefulness, } \\
\text { Perceived ease } \\
\text { of use, } \\
\text { Perceived } \\
\text { Behavioural } \\
\text { control, Trust, } \\
\text { Risk, Benefit } \\
\end{array}$ & $\begin{array}{l}\text { Intention to } \\
\text { book online }\end{array}$ & DTPB, TAM & $\begin{array}{l}\text { The Tourism Web Acceptance } \\
\text { Model (T-WAM) model, } \\
\text { ncorporating variables from } \\
\text { different fields of research, is a } \\
\text { robust model that explains } 50.6 \% \\
\text { of the variance for } \\
\text { booking tourism products online. } \\
\text { Thus, the T-WAM predicts } \\
\text { behavioral intention well, with } \\
\text { a considerable empirical } \\
\text { advantage compared to other } \\
\text { models used. }\end{array}$ \\
\hline 6 & $\begin{array}{l}\text { Nunkoo \& Ramkisson } \\
\text { (2013) }\end{array}$ & $\begin{array}{l}\text { To examine travelers } \\
\text { intention to purchase } \\
\text { tourism products online }\end{array}$ & Australia & $\begin{array}{l}\text { Self- } \\
\text { administered } \\
\text { survey }\end{array}$ & 438 ; tourists & SEM & $\begin{array}{l}\text { Attidude, } \\
\text { Perceived } \\
\text { usefulness, } \\
\text { Perceived ese of } \\
\text { use, Trust, } \\
\text { Perceived risk }\end{array}$ & $\begin{array}{l}\text { Intention to } \\
\text { book }\end{array}$ & TAM & $\begin{array}{l}\text { Perceived usefulness, trust, and } \\
\text { perceived risks are determinants } \\
\text { of attitude to e-purchasing, which } \\
\text { in turn significantly influences e- } \\
\text { purchase intent. Also, perceived } \\
\text { ease of use exerts a significant } \\
\text { influence on perceived usefulness } \\
\text { and trust while the latter } \\
\text { negatively influences perceived } \\
\text { risks. }\end{array}$ \\
\hline 7 & Lee (2009) & $\begin{array}{l}\text { To investigate how } \\
\text { destination image, } \\
\text { attitude, motivation } \\
\text { affect future behavior of } \\
\text { tourists }\end{array}$ & Taiwan & Face-to-face & 179 , tourists & SEM & $\begin{array}{l}\text { Satisfaction, } \\
\text { Image, Attitude, } \\
\text { Motivation }\end{array}$ & $\begin{array}{l}\text { Future } \\
\text { Behaviour }\end{array}$ & TPB & $\begin{array}{l}\text { Destination image is a critical } \\
\text { influence on tourist satisfaction in } \\
\text { wetland. }\end{array}$ \\
\hline 8 & Wen (2012) & $\begin{array}{l}\text { To investigate factors } \\
\text { affecting consumers' } \\
\text { online purchase intention }\end{array}$ & USA & Online survey & $\begin{array}{l}559, \text { online } \\
\text { travel buyers }\end{array}$ & SEM & $\begin{array}{l}\text { Trust, Quality } \\
\text { of website, } \\
\text { Attitude }\end{array}$ & $\begin{array}{l}\text { Purchase } \\
\text { intention }\end{array}$ & TPB & $\begin{array}{l}\text { Quality of website design was } \\
\text { had positive influence on } \\
\text { consumers attitude towards online } \\
\text { purchase of travel and tourism } \\
\text { products }\end{array}$ \\
\hline 9 & Liu \& Zhang (2014) & $\begin{array}{l}\text { To investigate the factors } \\
\text { influencing travelers } \\
\text { choice of online channel }\end{array}$ & China & $\begin{array}{l}\text { Mixed } \\
\text { method: } \\
\text { interviews } \\
\text { (operators); } \\
\text { online and } \\
\text { offline } \\
\text { questionnaire } \\
\text { administratio } \\
\text { n. }\end{array}$ & $\begin{array}{l}\text { 437, online } \\
\text { hotel bookers }\end{array}$ & SEM & $\begin{array}{l}\text { Information } \\
\text { search intention, } \\
\text { product related } \\
\text { factors, Channel } \\
\text { related factors }\end{array}$ & $\begin{array}{l}\text { Purchase } \\
\text { intention }\end{array}$ & $\begin{array}{l}\text { Purchase } \\
\text { intention }\end{array}$ & $\begin{array}{l}\text { All hypotheses were supported. } \\
\text { That is information search } \\
\text { intention, product related factors } \\
\text { and channel related factors } \\
\text { positive influenced purchase } \\
\text { intention. }\end{array}$ \\
\hline 10 & Castaneda, Frias, & To investigate the factors & Spain & Fact-to-face, & 340 , tourists & SEM & Future use, & Actual use & TAM & Perceived usefulness is having \\
\hline
\end{tabular}




\begin{tabular}{|c|c|c|c|c|c|c|c|c|c|c|}
\hline & Rodriquez (2009) & $\begin{array}{l}\text { driving ICT as a source } \\
\text { of information in the } \\
\text { tourism business }\end{array}$ & & & & & $\begin{array}{l}\text { Attitude, } \\
\text { Usefulness, } \\
\text { Ease of use }\end{array}$ & & & $\begin{array}{l}\text { stronger effect on actual use than } \\
\text { perceived ease of use. }\end{array}$ \\
\hline 11 & Sparks \& Pan (2009) & $\begin{array}{l}\text { To investigate Chinese } \\
\text { outbound tourist's values } \\
\text { in terms of destination } \\
\text { attributes and attitudes } \\
\text { towards international } \\
\text { travel }\end{array}$ & China & Face-to-face & $\begin{array}{l}\text { 496, Chinese } \\
\text { tourists }\end{array}$ & SEM & $\begin{array}{l}\text { Subjective } \\
\text { norm, Attitude, } \\
\text { Constraints and } \\
\text { perceived } \\
\text { control, } \\
\text { Importance of } \\
\text { destination } \\
\text { attributes, } \\
\text { Likelihood of } \\
\text { Australia, } \\
\text { Information } \\
\text { sources } \\
\end{array}$ & $\begin{array}{l}\text { Intention to visit } \\
\text { Australia }\end{array}$ & TPB & $\begin{array}{l}\text { Subjective norm was positively } \\
\text { related to behavioural intention to } \\
\text { travel. }\end{array}$ \\
\hline 12 & $\begin{array}{l}\text { Herrero \& Martin } \\
(2012)\end{array}$ & $\begin{array}{l}\text { To investigate factors } \\
\text { influencing the use of } \\
\text { rural tourism } \\
\text { accommodation website }\end{array}$ & Spain & Face-to-face & $\begin{array}{l}\text { 1083, Spanish } \\
\text { tourism web } \\
\text { users }\end{array}$ & SEM & $\begin{array}{l}\text { Perceived } \\
\text { usefulness, } \\
\text { (information n } \\
\text { accommodation } \\
\text {, information on } \\
\text { destination } \\
\text { Perceived ease } \\
\text { of use } \\
\text { (interactivity of } \\
\text { the website, } \\
\text { navigability of } \\
\text { the website) }\end{array}$ & Intention & TAM & $\begin{array}{l}\text { Perceived usefulness and } \\
\text { perceived ease of use positively } \\
\text { influenced intention }\end{array}$ \\
\hline 13 & $\begin{array}{l}\text { Al-hawari \& } \\
\text { Mouakket (2012) }\end{array}$ & $\begin{array}{l}\text { To investigate how } \\
\text { offline factors trigger } \\
\text { online continual usage } \\
\text { by customers of airline } \\
\text { e-ticket booking services }\end{array}$ & UAE & Face-to-face & 258, students & SEM & $\begin{array}{l}\text { Image, Trust, } \\
\text { Employee- } \\
\text { based service } \\
\text { quality, } \\
\text { Subjective norm }\end{array}$ & $\begin{array}{l}\text { Online } \\
\text { continual Usage }\end{array}$ & $\begin{array}{l}\text { TTPT, CDT, } \\
\text { IDT }\end{array}$ & $\begin{array}{l}\text { Employee-based service quality } \\
\text { was provided to have high, } \\
\text { significant and positive } \\
\text { relationship with pre-existing } \\
\text { offline trust and pre-existing } \\
\text { offline image }\end{array}$ \\
\hline 14 & $\begin{array}{l}\text { Kim, Lee, Lee \& } \\
\text { Song (2012) }\end{array}$ & $\begin{array}{l}\text { To examine the factors } \\
\text { influencing travel } \\
\text { decisions overseas } \\
\text { among women }\end{array}$ & $\begin{array}{l}\text { Republic of } \\
\text { Korea }\end{array}$ & Online survey & $\begin{array}{l}400 ; \text { South } \\
\text { Korean } \\
\text { tourists }\end{array}$ & SEM & $\begin{array}{l}\text { Behavioural } \\
\text { desire, Attitude, } \\
\text { Subjective } \\
\text { Norms, } \\
\text { Negative } \\
\text { anticipated } \\
\text { emotions, } \\
\text { Positive } \\
\text { anticipated } \\
\text { emotions }\end{array}$ & $\begin{array}{l}\text { Behavioural } \\
\text { intention }\end{array}$ & $\begin{array}{l}\text { MGB, TRA, } \\
\text { TPB }\end{array}$ & $\begin{array}{l}\text { All hypotheses were supported. } \\
\text { Attitude, subjective norms, } \\
\text { negative anticipated emotions, } \\
\text { and positive anticipated had a } \\
\text { significant effect on behavioural } \\
\text { desire. }\end{array}$ \\
\hline 15 & $\operatorname{Lin}(2010)$ & $\begin{array}{l}\text { To investigate the factors } \\
\text { influencing the users } \\
\text { acceptance or rejection } \\
\text { of e-travel sites }\end{array}$ & Taiwan & Online survey & $\begin{array}{l}\text { 242, students } \\
\text { in Taiwan }\end{array}$ & SEM & $\begin{array}{l}\text { Perceived ease } \\
\text { of use, } \\
\text { Perceived } \\
\text { usefulness, User } \\
\text { interface, }\end{array}$ & $\begin{array}{l}\text { Behavioural } \\
\text { intention }\end{array}$ & TAM & $\begin{array}{l}\text { All hypotheses were supported } \\
\text { except functionality and } \\
\text { perceived usefulness }\end{array}$ \\
\hline
\end{tabular}




\begin{tabular}{|c|c|c|c|c|c|c|c|c|c|c|}
\hline & & & & & & & $\begin{array}{l}\text { Information } \\
\text { quality, } \\
\text { functionality }\end{array}$ & & & \\
\hline 16 & $\begin{array}{l}\text { Huang, Backman, } \\
\text { Backman \& Moore } \\
\text { (2013) }\end{array}$ & $\begin{array}{l}\text { To investigate using } \\
\text { TAM, tourists' } \\
\text { experience and } \\
\text { behavioural intention } \\
\text { within a 3D tourism } \\
\text { destination }\end{array}$ & USA & online survey & $\begin{array}{l}\text { 198, students } \\
\text { and 3D users }\end{array}$ & SEM & $\begin{array}{l}\text { Enjoyment, } \\
\text { Positive } \\
\text { emotion, } \\
\text { Emotional } \\
\text { involvement, } \\
\text { Flow, Perceived } \\
\text { ease of use, } \\
\text { Perceived } \\
\text { usefulness }\end{array}$ & $\begin{array}{l}\text { Behavioural } \\
\text { intention }\end{array}$ & TAM & $\begin{array}{l}\text { Perceived ease of use and } \\
\text { perceived usefulness positively } \\
\text { influenced enjoyment. Positive } \\
\text { emotion, emotional involvement } \\
\text { and flow has positive and } \\
\text { significant influence on } \\
\text { behavioural intentions. }\end{array}$ \\
\hline 17 & $\begin{array}{l}\text { Kim, Kim \& Shin } \\
(2009)\end{array}$ & $\begin{array}{l}\text { To examine the factors } \\
\text { influencing the } \\
\text { acceptance of airline } \\
\text { B2C ecommerce } \\
\text { websites }\end{array}$ & $\begin{array}{l}\text { Republic of } \\
\text { Korea }\end{array}$ & Online survey & $\begin{array}{l}495, \text { Korean } \\
\text { airline } \\
\text { customers }\end{array}$ & SEM & $\begin{array}{l}\text { Subjective } \\
\text { norms, Attitude, } \\
\text { eTrust, } \\
\text { Perceived } \\
\text { usefulness, } \\
\text { Perceived ease } \\
\text { of use }\end{array}$ & Intenti & TAM & All hypotheses were supported. \\
\hline 18 & Wen (2013) & $\begin{array}{l}\text { To examine the impact } \\
\text { of factors influencing } \\
\text { travelers' attitude on } \\
\text { online shopping } \\
\text { intentions }\end{array}$ & USA & Online survey & $\begin{array}{l}560 \\
\text { American } \\
\text { tourists }\end{array}$ & SEM & $\begin{array}{l}\text { Perception of } \\
\text { convenience, } \\
\text { Perception of } \\
\text { merchandise, } \\
\text { Perception of } \\
\text { Value, } \\
\text { Shopping } \\
\text { experience }\end{array}$ & $\begin{array}{l}\text { Purchase } \\
\text { Intention }\end{array}$ & TPB & $\begin{array}{l}\text { Travelers have a more positive } \\
\text { attitude toward travel portal } \\
\text { websites than toward companies' } \\
\text { branded websites in terms of } \\
\text { perception of convenience, } \\
\text { perception of merchandise and } \\
\text { perception of value }\end{array}$ \\
\hline 19 & $\begin{array}{l}\text { Hosany \& Prayag } \\
\text { (2013) }\end{array}$ & $\begin{array}{l}\text { To examine tourists } \\
\text { emotional profiles and } \\
\text { their post-consumption } \\
\text { evaluations of } \\
\text { satisfaction and intention } \\
\text { to recommend }\end{array}$ & UK & Postal survey & $\begin{array}{l}\text { 520, English } \\
\text { tourists }\end{array}$ & SEM & $\begin{array}{l}\text { Joy, Love, } \\
\text { Positive } \\
\text { surprise, } \\
\text { Unpleasantness, }\end{array}$ & $\begin{array}{l}\text { Satisfaction, } \\
\text { Intention to } \\
\text { recommend }\end{array}$ & CNTT & $\begin{array}{l}\text { Tourists who were delighted were } \\
\text { seen to recommend the } \\
\text { destination to others. }\end{array}$ \\
\hline 20 & Lee \& Cranage (2011) & $\begin{array}{l}\text { To examine how privacy } \\
\text { assurance affects } \\
\text { personalization and the } \\
\text { role it plays in } \\
\text { influencing behavioural } \\
\text { responses }\end{array}$ & USA & $\begin{array}{l}\text { Experiment } \\
\text { (website } \\
\text { analysis) }\end{array}$ & $\begin{array}{l}120, \\
\text { undergraduate } \\
\text { student }\end{array}$ & $\begin{array}{l}\text { Analysis of } \\
\text { variance } \\
\text { (ANOVA) } \\
\text { and } \\
\text { Analysis of } \\
\text { covariance } \\
\text { (ANCOVA) }\end{array}$ & $\begin{array}{l}\text { Perceived } \\
\text { usefulness, } \\
\text { Privacy } \\
\text { concern, } \\
\text { Personalization, } \\
\text { Privacy } \\
\text { assurance }\end{array}$ & $\begin{array}{l}\text { Adoption } \\
\text { intention, Self- } \\
\text { Disclosure } \\
\text { intention }\end{array}$ & $\begin{array}{l}\text { Personalisatio } \\
\mathrm{n}\end{array}$ & $\begin{array}{l}\text { Enhancing privacy assurance } \\
\text { increases the perceived usefulness } \\
\text { of services and decreases } \\
\text { customer privacy concerns. } \\
\text { Behavioural responses are } \\
\text { positively related to the perceived } \\
\text { usefulness of services }\end{array}$ \\
\hline 21 & $\begin{array}{l}\text { Chow \& Murphy } \\
\text { (2011) }\end{array}$ & $\begin{array}{l}\text { To explore the predictive } \\
\text { power of psychographic } \\
\text { and demographic } \\
\text { variables on intended } \\
\text { and actual travel } \\
\text { behaviours }\end{array}$ & China & $\begin{array}{l}\text { Triangulation } \\
\text { (Qual } \\
\text { interviews); } \\
\text { Face-to-face } \\
\text { and survey }\end{array}$ & $\begin{array}{l}\text { 397, Chinese } \\
\text { outbound } \\
\text { tourists }\end{array}$ & $\begin{array}{l}\text { Multiple } \\
\text { regression }\end{array}$ & $\begin{array}{l}\text { Sightseeing, } \\
\text { Culture and } \\
\text { heritage } \\
\text { activity, } \\
\text { Shopping and } \\
\text { Dining and } \\
\text { Entertainment }\end{array}$ & $\begin{array}{l}\text { Intention and } \\
\text { Actual travel } \\
\text { behavior }\end{array}$ & Intend, Actual & $\begin{array}{l}\text { Actual and intention to travel } \\
\text { were influenced by sightseeing, } \\
\text { culture and heritage activity, } \\
\text { shopping and dining, and } \\
\text { entertainment. }\end{array}$ \\
\hline 22 & Chen \& Kao (2010) & To investigate the effects & Taiwan & Face-to-face & 240 , & SEM & Process quality, & Behavioural & SERVQUAL & Tourists who are satisfied show \\
\hline
\end{tabular}




\begin{tabular}{|c|c|c|c|c|c|c|c|c|c|c|}
\hline & & $\begin{array}{l}\text { of process quality, } \\
\text { outcome quality, } \\
\text { satisfaction and } \\
\text { behavioural intentions } \\
\text { on online travel agencies }\end{array}$ & & & $\begin{array}{l}\text { Taiwanese } \\
\text { tourists }\end{array}$ & & $\begin{array}{l}\text { Outcome } \\
\text { quality }\end{array}$ & $\begin{array}{l}\text { intention, } \\
\text { Satisfaction }\end{array}$ & & $\begin{array}{l}\text { favourable behavioural intention } \\
\text { towards the destination }\end{array}$ \\
\hline 23 & $\begin{array}{l}\text { Wu, Chiu, Yang \& Li } \\
\text { (2011) }\end{array}$ & $\begin{array}{l}\text { To determine factors } \\
\text { influencing tourism } \\
\text { website usability }\end{array}$ & Taiwan & Face-to-face & $\begin{array}{l}256, \\
\text { Taiwanese } \\
\text { tourists }\end{array}$ & SEM & $\begin{array}{l}\text { Performance } \\
\text { expectancy, } \\
\text { Effort } \\
\text { expectancy, } \\
\text { Social } \\
\text { Influence, } \\
\text { Facilitating } \\
\text { conditions, } \\
\text { Behavioural } \\
\text { intention } \\
\end{array}$ & Use behavior & UTAUT & $\begin{array}{l}\text { Performance expectancy, effort } \\
\text { expectancy, social influence, } \\
\text { facilitating conditions all } \\
\text { influence behavioural intention. } \\
\text { On the other hand, behavioural } \\
\text { intention influences use behavior }\end{array}$ \\
\hline 24 & $\begin{array}{l}\text { Martin \& Herrero } \\
\text { (2012) }\end{array}$ & $\begin{array}{l}\text { To determine factors } \\
\text { influencing users' } \\
\text { psychological factors on } \\
\text { online purchase intention }\end{array}$ & Spain & Face-to-face & $\begin{array}{l}\text { 1083, Spanish } \\
\text { rural tourists }\end{array}$ & $\begin{array}{l}\text { Regression } \\
\text { analysis }\end{array}$ & $\begin{array}{l}\text { Performance } \\
\text { expectancy, } \\
\text { Effort } \\
\text { expectancy, } \\
\text { Social } \\
\text { influence, } \\
\text { Facilitating } \\
\text { conditions, } \\
\text { Innovativeness } \\
\end{array}$ & $\begin{array}{l}\text { Online purchase } \\
\text { intention }\end{array}$ & UTAUT & $\begin{array}{l}\text { Purchase intention depends on } \\
\text { user performance and effort } \\
\text { expected by the user. Also, the } \\
\text { higher the innovativeness of the } \\
\text { user the higher the purchase } \\
\text { intention. }\end{array}$ \\
\hline 25 & $\begin{array}{l}\text { Escobar-Rodriguez \& } \\
\text { Carvajal-Trujillo } \\
\text { (2014) }\end{array}$ & $\begin{array}{l}\text { To determine factors } \\
\text { influencing purchase of } \\
\text { flights from low-cost } \\
\text { carrier websites }\end{array}$ & Spain & Face-to-face & $\begin{array}{l}\text { 1096, Spanish } \\
\text { travelers }\end{array}$ & SEM & $\begin{array}{l}\text { Performance } \\
\text { expectancy, } \\
\text { Effort } \\
\text { expectancy, } \\
\text { Social } \\
\text { influence, } \\
\text { Facilitating } \\
\text { conditions, } \\
\text { Hedonic } \\
\text { motivation, } \\
\text { Price saving } \\
\text { orientation, } \\
\text { Habit, } \\
\text { Innovativeness, } \\
\text { Trust, } \\
\text { Information } \\
\text { quality, } \\
\text { Perceived } \\
\text { security, } \\
\text { Perceived } \\
\text { privacy, } \\
\text { Behavioural } \\
\text { intention }\end{array}$ & Use Behaviour & UTAUT & $\begin{array}{l}\text { In order of importance, the } \\
\text { predictors of online purchase } \\
\text { intention are trust, habit, price } \\
\text { saving, facilitating conditions, } \\
\text { performance expectancy, effort } \\
\text { expectancy, innovativeness, } \\
\text { hedonic motivation and social } \\
\text { influence. }\end{array}$ \\
\hline 26 & Rasty, Chou \& Feiz & To investigate the role of & Iran & Online survey & 386 , tourists & SEM & Internet travel & Purchase & $\mathrm{ADC}$ & Those who purchase travel \\
\hline
\end{tabular}




\begin{tabular}{|c|c|c|c|c|c|c|c|c|c|c|}
\hline & (2013) & $\begin{array}{l}\text { internet advertising } \\
\text { design, tourists attitude } \\
\text { and internet travel } \\
\text { advertising effect on } \\
\text { tourist's purchase } \\
\text { intention }\end{array}$ & & & in Iran & & $\begin{array}{l}\text { advertising } \\
\text { effect, Internet } \\
\text { advertising } \\
\text { attitude, Internet } \\
\text { travel } \\
\text { advertising } \\
\text { content design, } \\
\text { Involvement }\end{array}$ & intention & & $\begin{array}{l}\text { products are those who are highly } \\
\text { involved. Also, Those who have } \\
\text { positive internet ad attitude are } \\
\text { found to have high purchase } \\
\text { intention }\end{array}$ \\
\hline 27 & $\begin{array}{l}\text { Kucukusta, Law, } \\
\text { Besbes \& Legoherel } \\
\text { (2015) }\end{array}$ & $\begin{array}{l}\text { To investigate factors } \\
\text { influencing Hong Kong } \\
\text { online users' intention to } \\
\text { book tourism products }\end{array}$ & Hong Kong & Face-to-face & $\begin{array}{l}213 \text {, Hong } \\
\text { Kong online } \\
\text { users }\end{array}$ & $\begin{array}{l}\text { ANOVA, } \\
\text { regression } \\
\text { analysis }\end{array}$ & $\begin{array}{l}\text { Perceived } \\
\text { usefulness, Ease } \\
\text { of use }\end{array}$ & $\begin{array}{l}\text { Behavioural } \\
\text { intention }\end{array}$ & TAM & $\begin{array}{l}\text { Perceived usefulness is found to } \\
\text { be more influential than ease of } \\
\text { use in predicting intention to } \\
\text { book for tourism products }\end{array}$ \\
\hline 28 & $\begin{array}{l}\text { Munoz-Leiva, } \\
\text { Hernandez-Mendez \& } \\
\text { Sanchez-Fernandez } \\
(2012)\end{array}$ & $\begin{array}{l}\text { To investigate the factors } \\
\text { influencing tourists' use } \\
\text { behavior of travel } 2.0 \\
\text { websites }\end{array}$ & Spain & Online survey & $\begin{array}{l}440, \text { Spanish } \\
\text { travel } 2.0 \\
\text { website users }\end{array}$ & SEM & $\begin{array}{l}\text { Trust, } \\
\text { Usefulness, } \\
\text { Attitude, Ease } \\
\text { of use }\end{array}$ & Intention & TAM & $\begin{array}{l}\text { Differences in website determines } \\
\text { the behavior of the user }\end{array}$ \\
\hline 29 & $\begin{array}{l}\text { Hsu, Chang \& Chen } \\
\text { (2012) }\end{array}$ & $\begin{array}{l}\text { The examine the impact } \\
\text { of website quality on } \\
\text { customer satisfaction } \\
\text { and purchase intention }\end{array}$ & Taiwan & Online survey & $\begin{array}{l}534, \\
\text { Taiwanese } \\
\text { tourists }\end{array}$ & SEM & $\begin{array}{l}\text { Perceived } \\
\text { playfulness, } \\
\text { Perceived flow, } \\
\text { Information } \\
\text { quality, System } \\
\text { quality, Service } \\
\text { quality }\end{array}$ & $\begin{array}{l}\text { Purchase } \\
\text { intention, } \\
\text { Customer } \\
\text { satisfaction }\end{array}$ & SOR & $\begin{array}{l}\text { Service quality is very important } \\
\text { in predicting customer } \\
\text { satisfaction and purchase } \\
\text { intention }\end{array}$ \\
\hline 30 & $\begin{array}{l}\text { Kaplanidou \& Vogt } \\
\text { (2006) }\end{array}$ & $\begin{array}{l}\text { To examine the role of } \\
\text { website influencing } \\
\text { travel intentions }\end{array}$ & USA & Online survey & $\begin{array}{l}2,342 \\
\text { American } \\
\text { online travel } \\
\text { buyers }\end{array}$ & SEM & $\begin{array}{l}\text { Accessibility, } \\
\text { Usefulness, } \\
\text { Ease of } \\
\text { navigation, } \\
\text { content } \\
\text { motivating } \\
\text { visuals, Content } \\
\text { trip info } \\
\text { functionality }\end{array}$ & Intention & TAM & $\begin{array}{l}\text { Website usefulness was an } \\
\text { important factor in predicting } \\
\text { online travel }\end{array}$ \\
\hline 31 & $\begin{array}{l}\text { Lee, Qu \& Kim } \\
(2007)\end{array}$ & $\begin{array}{l}\text { To examine how online } \\
\text { traveler decision-making } \\
\text { is influenced by } \\
\text { innovativeness }\end{array}$ & $\begin{array}{l}\text { Republic of } \\
\text { Korea }\end{array}$ & Online survey & $\begin{array}{l}235, \text { South } \\
\text { Korean } \\
\text { travelers }\end{array}$ & SEM & $\begin{array}{l}\text { Attitude, } \\
\text { Subjective } \\
\text { norm, } \\
\text { Innovativeness }\end{array}$ & Intention & TRA & $\begin{array}{l}\text { Highly innovative travelers were } \\
\text { influenced by their positive } \\
\text { attitudes }\end{array}$ \\
\hline 32 & Kamarulzaman (2007) & $\begin{array}{l}\text { To explore consumers' } \\
\text { adoption of internet } \\
\text { shopping on travel } \\
\text { services }\end{array}$ & UK & Online survey & $\begin{array}{l}300 \text { UK travel } \\
\text { shoppers }\end{array}$ & SEM & $\begin{array}{l}\text { Trust, Perceived } \\
\text { risk, Perceived } \\
\text { ease of use, } \\
\text { Perceived } \\
\text { usefulness, } \\
\text { Innovativeness, } \\
\text { Involvement, } \\
\text { Opinion } \\
\text { Leadership }\end{array}$ & Intention & TAM & $\begin{array}{l}\text { Individual traits are important in } \\
\text { perceived useful in adopting new } \\
\text { technology }\end{array}$ \\
\hline
\end{tabular}




\begin{tabular}{|c|c|c|c|c|c|c|c|c|c|c|}
\hline 33 & Wong \& Law (2005) & $\begin{array}{l}\text { To understand the } \\
\text { factors influencing hotel } \\
\text { bookers reservation of } \\
\text { rooms through websites }\end{array}$ & Hong Kong & $\begin{array}{l}\text { Omnibus } \\
\text { survey (Face } \\
\text { to face) }\end{array}$ & $\begin{array}{l}638 \text { Hong } \\
\text { Kong } \\
\text { travelers }\end{array}$ & $\begin{array}{l}\text { Regression } \\
\text { analysis }\end{array}$ & $\begin{array}{l}\text { Information } \\
\text { quality, } \\
\text { Sensitivity } \\
\text { content, Time }\end{array}$ & Intention & Motivation & $\begin{array}{l}\text { Information available on the } \\
\text { website was important } \\
\text { influencing hotel booking through } \\
\text { website }\end{array}$ \\
\hline 34 & $\begin{array}{l}\text { Luque-Martinez et al } \\
\text { (2007) }\end{array}$ & $\begin{array}{l}\text { To explore the factors } \\
\text { influencing the } \\
\text { intentions to use internet } \\
\text { to search for holiday } \\
\text { information }\end{array}$ & Spain & Face to face & $\begin{array}{l}286 \\
\text { international } \\
\text { tourists in } \\
\text { Spain }\end{array}$ & SEM & $\begin{array}{l}\text { Satisfaction, } \\
\text { Attitude, Ease } \\
\text { of use, } \\
\text { Usefulness }\end{array}$ & Intention & TAM & $\begin{array}{l}\text { The TAM model explicitly } \\
\text { explains intentions but should be } \\
\text { expanded to incorporate } \\
\text { satisfaction on online context }\end{array}$ \\
\hline 35 & $\begin{array}{l}\text { Kim, Ma \& Kim } \\
\text { (2006) }\end{array}$ & $\begin{array}{l}\text { To investigate the factors } \\
\text { influencing Chinese } \\
\text { online reservations } \\
\text { intentions }\end{array}$ & China & Face to face & $\begin{array}{l}206 \text { guests in } \\
\text { a Chinese } \\
\text { hotel }\end{array}$ & $\begin{array}{l}\text { Regression } \\
\text { analysis }\end{array}$ & $\begin{array}{l}\text { Information } \\
\text { needs, Service } \\
\text { performance \& } \\
\text { reputation, } \\
\text { Convenience, } \\
\text { Price benefits, } \\
\text { Technological } \\
\text { inclination, } \\
\text { Safety }\end{array}$ & $\begin{array}{l}\text { Intention, e- } \\
\text { Satisfaction }\end{array}$ & $\begin{array}{l}\text { Customer } \\
\text { satisfaction }\end{array}$ & $\begin{array}{l}\text { Security and information were the } \\
\text { most important consideration for } \\
\text { booking a hotel through a website }\end{array}$ \\
\hline 36 & Ryan \& Rao (2008) & $\begin{array}{l}\text { To investigate holiday } \\
\text { users of internet ease of } \\
\text { use, functionality and } \\
\text { novelty of hotel websites }\end{array}$ & $\begin{array}{l}\text { New } \\
\text { Zealand }\end{array}$ & Face to face & $\begin{array}{l}440, \\
\text { International } \\
\text { visitors to } \\
\text { New Zealand }\end{array}$ & SEM & $\begin{array}{l}\text { Secure system, } \\
\text { Perceived ease } \\
\text { of use, } \\
\text { Perceived } \\
\text { usefulness, } \\
\text { Behaviour }\end{array}$ & Intention & TAM & $\begin{array}{l}\text { Security is an important } \\
\text { consideration on hotel booking }\end{array}$ \\
\hline 37 & Jarvelainen (2007) & $\begin{array}{l}\text { To investigate factors } \\
\text { that influence } \\
\text { consumers' online } \\
\text { purchase of travel } \\
\text { products in a secure } \\
\text { environment }\end{array}$ & Finland & Online survey & $\begin{array}{l}\text { 1501 Finnish } \\
\text { internet users }\end{array}$ & SEM & $\begin{array}{l}\text { Perceived } \\
\text { usefulness, } \\
\text { Perceived ease } \\
\text { of use, Prior } \\
\text { online } \\
\text { experience, } \\
\text { Task ambiguity, } \\
\text { Social } \\
\text { environment }\end{array}$ & Intention & $\begin{array}{l}\text { TAM, MRT, } \\
\text { SIM }\end{array}$ & $\begin{array}{l}\text { Perceived usefulness has a } \\
\text { stronger effect on behavioural } \\
\text { intention than perceived ease of } \\
\text { use. }\end{array}$ \\
\hline 38 & Chen (2007) & $\begin{array}{l}\text { To examine the factors } \\
\text { influencing online } \\
\text { purchase of airline } \\
\text { tickets }\end{array}$ & Taiwan & Face to face & $\begin{array}{l}355 \text { free } \\
\text { independent } \\
\text { Taiwanese } \\
\text { travelers }\end{array}$ & SEM & $\begin{array}{l}\text { Attitude, Social } \\
\text { support, } \\
\text { Perceived } \\
\text { confidence, } \\
\text { compatibility, } \\
\text { Relative } \\
\text { advantage, } \\
\text { Complexity, } \\
\text { Peer Influence, } \\
\text { External } \\
\text { Influence, } \\
\text { Perceived } \\
\text { Capability }\end{array}$ & Intention & DTPB & $\begin{array}{l}\text { Online purchase of tickets will } \\
\text { continue to grow as users show } \\
\text { positive attitude }\end{array}$ \\
\hline 39 & $\begin{array}{l}\text { Bai, Law \& Wen } \\
(2008)\end{array}$ & $\begin{array}{l}\text { To test a conceptual } \\
\text { model of website quality }\end{array}$ & China & Face to face & $\begin{array}{l}180 \text { hotel } \\
\text { guests }\end{array}$ & SEM & $\begin{array}{l}\text { Functionality, } \\
\text { Usability, }\end{array}$ & Intention & SERVQUAL & $\begin{array}{l}\text { Website quality positively } \\
\text { influences customer satisfaction }\end{array}$ \\
\hline
\end{tabular}




\begin{tabular}{|c|c|c|c|c|c|c|c|c|c|c|}
\hline & & $\begin{array}{l}\text { on customer satisfaction } \\
\text { and purchase intention }\end{array}$ & & & & & $\begin{array}{l}\text { Customer } \\
\text { satisfaction }\end{array}$ & & & $\begin{array}{l}\text { and it in turn influences purchase } \\
\text { intentions }\end{array}$ \\
\hline 40 & $\begin{array}{l}\text { Morosan \& Jeong } \\
(2008)\end{array}$ & $\begin{array}{l}\text { To explore if the } \\
\text { modified TAM can } \\
\text { evaluate users evaluation } \\
\text { of different channels of } \\
\text { hotel online reservations }\end{array}$ & USA & Online & $\begin{array}{l}914, \text { US } \\
\text { students }\end{array}$ & SEM & $\begin{array}{l}\text { Perceived } \\
\text { usefulness, } \\
\text { Perceived ease } \\
\text { of use, } \\
\text { Perceived } \\
\text { playfulness, } \\
\text { Attitude } \\
\end{array}$ & Intention & TAM & $\begin{array}{l}\text { Perceived usefulness was a strong } \\
\text { predictor of attitude }\end{array}$ \\
\hline \multicolumn{11}{|c|}{ Consumer adoption of social media in tourism (CASMT) } \\
\hline 1 & $\begin{array}{l}\text { Filieri \& McLeay } \\
\text { (2013) }\end{array}$ & $\begin{array}{l}\text { To investigate the } \\
\text { behavioural } \\
\text { consequences of e-wom }\end{array}$ & Italy & $\begin{array}{l}\text { Online } \\
\text { survey; }\end{array}$ & $\begin{array}{l}578 ; \\
\text { individuals }\end{array}$ & SEM & $\begin{array}{l}\text { Product } \\
\text { ranking, } \\
\text { Information } \\
\text { accuracy, } \\
\text { Information } \\
\text { quantity, } \\
\text { Information } \\
\text { relevance, } \\
\text { Information } \\
\text { value added, } \\
\text { Information } \\
\text { understanding, } \\
\text { Information } \\
\text { timeliness, } \\
\text { Information } \\
\text { completeness } \\
\text { and Information } \\
\text { adoption }\end{array}$ & $\begin{array}{l}\text { Information } \\
\text { Adoption }\end{array}$ & ELM & $\begin{array}{l}\text { Central routes - information timeliness, } \\
\text { information understandability, } \\
\text { information relevance, information } \\
\text { accuracy, value-added information and } \\
\text { information completeness; and } \\
\text { peripheral route - information quality, } \\
\text { product ranking were all seen to predict } \\
\text { tourist choice of destination }\end{array}$ \\
\hline 2 & $\begin{array}{l}\text { Parra-Lopez, } \\
\text { Bulchand-Gidumal, } \\
\text { Gutierrez-Tano \& } \\
\text { Diaz-Armas (2011) }\end{array}$ & $\begin{array}{l}\text { To examine the factors } \\
\text { that influence the use of } \\
\text { social media to take } \\
\text { travel online }\end{array}$ & Spain & Online survey & $\begin{array}{l}404, \\
\text { individuals } \\
\text { who take } \\
\text { travel online }\end{array}$ & SEM & $\begin{array}{l}\text { Incentives on } \\
\text { use and } \\
\text { adoption (, } \\
\text { Benefits of use, } \\
\text { Costs of use }\end{array}$ & $\begin{array}{l}\text { Intentions of } \\
\text { using social } \\
\text { media }\end{array}$ & INT & $\begin{array}{l}\text { Intentions to use social media are } \\
\text { directly influenced by the } \\
\text { perceived benefits of that use } \\
\text { (functional, psychological and hedonic } \\
\text { and social); however, the costs do not } \\
\text { significantly affect the predisposition to } \\
\text { use such technologies. It is also shown } \\
\text { that there is a series } \\
\text { of incentives such as altruism, } \\
\text { availability, individual predisposition or } \\
\text { trust in the contributions of others } \\
\text { which facilitate and promote the use of } \\
\text { this type of technology when organizing } \\
\text { and taking tourist trips }\end{array}$ \\
\hline 3 & $\begin{array}{l}\text { Book, Tanford, } \\
\text { Montgomery \& Love } \\
\text { (2015) }\end{array}$ & $\begin{array}{l}\text { To examine the role of } \\
\text { price on online travel } \\
\text { reviews }\end{array}$ & USA & $\begin{array}{l}\text { Hand- } \\
\text { delivered } \\
\text { questionnaire }\end{array}$ & $\begin{array}{l}327, \\
\text { undergraduate } \\
\text { students }\end{array}$ & $\begin{array}{l}\text { MANCO } \\
\text { VA, } \\
\text { ANOVA }\end{array}$ & $\begin{array}{l}\text { Customer } \\
\text { reviews, Price, } \\
\text { Dissonance, }\end{array}$ & $\begin{array}{l}\text { Intention to } \\
\text { purchase } \\
\text { travel }\end{array}$ & CDT & $\begin{array}{l}\text { Social influence had a strong effect on } \\
\text { both resort evaluations and postdecision } \\
\text { dissonance. Nonunani mous reviews } \\
\text { reduced the prevailing valence of }\end{array}$ \\
\hline
\end{tabular}




\begin{tabular}{|c|c|c|c|c|c|c|c|c|c|c|}
\hline & & & & & & & & & & $\begin{array}{l}\text { reviews, but increased dissonance. Price } \\
\text { may not be the predominant influence on } \\
\text { decisions, as previously thought. }\end{array}$ \\
\hline 4 & $\begin{array}{l}\text { Casalo, Flavian \& } \\
\text { Guinaliu (2010) }\end{array}$ & $\begin{array}{l}\text { To investigate the factors } \\
\text { influencing intention to } \\
\text { participation in firm- } \\
\text { hostel online travel } \\
\text { communities }\end{array}$ & Spain & Online survey & $\begin{array}{l}456, \text { online } \\
\text { community } \\
\text { members }\end{array}$ & SEM & $\begin{array}{l}\text { Attitude, } \\
\text { Subject norm, } \\
\text { Perceived } \\
\text { behavioural } \\
\text { control, } \\
\text { Perceived } \\
\text { usefulness, } \\
\text { Perceived ease } \\
\text { of use, } \\
\text { Identification }\end{array}$ & $\begin{array}{l}\text { Intention to } \\
\text { participate }\end{array}$ & $\begin{array}{l}\text { TPB, TAM } \\
\& \text { SIT }\end{array}$ & $\begin{array}{l}\text { Subjective norm was not supported. } \\
\text { Attitude, perceived behavioural control, } \\
\text { perceived usefulness, perceived ease of } \\
\text { use were all supported. }\end{array}$ \\
\hline 5 & $\begin{array}{l}\text { Ayeh, Au \& Law } \\
\text { (2013) }\end{array}$ & $\begin{array}{l}\text { To examine online } \\
\text { traveller's perception of } \\
\text { the credibility of User } \\
\text { Generated Content }\end{array}$ & Singapore & Online survey & $\begin{array}{l}661, \\
\text { Singaporean } \\
\text { tourists }\end{array}$ & SEM & $\begin{array}{l}\text { Attitude, } \\
\text { Trust worthiness } \\
\text {, Expertise, } \\
\text { Homophily }\end{array}$ & Intention & $\begin{array}{l}\text { Source } \\
\text { Credibility }\end{array}$ & $\begin{array}{l}\text { There is significant support for the } \\
\text { impact of source credibility perceptions } \\
\text { on attitude. All hypothesis were } \\
\text { supported }\end{array}$ \\
\hline 6 & $\begin{array}{l}\text { Wang (2011) } \\
\text { ) }\end{array}$ & $\begin{array}{l}\text { To investigate the factors } \\
\text { influencing gastronomy } \\
\text { blogs in predicting } \\
\text { readers' intention to taste } \\
\text { local food and beverages }\end{array}$ & Taiwan & online survey & 329 , bloggers & SEM & $\begin{array}{l}\text { Inspiring taste } \\
\text { desire, Forming } \\
\text { taste awareness, } \\
\text { Facilitating } \\
\text { interpersonal } \\
\text { interaction }\end{array}$ & $\begin{array}{l}\text { Behavioural } \\
\text { intention }\end{array}$ & e-WOM & $\begin{array}{l}\text { Experiencing appeal, generating } \\
\text { empathy, providing image, presenting } \\
\text { guides, social influence and } \\
\text { cybercommunity were positively related } \\
\text { to behavioural intention. Delivering } \\
\text { knowledge was not found to be positive. }\end{array}$ \\
\hline 7 & $\begin{array}{l}\text { Sparks, Perkins \& } \\
\text { Buckley (2013) }\end{array}$ & $\begin{array}{l}\text { To examine the } \\
\text { influence of online travel } \\
\text { reviews on attitudes and } \\
\text { purchase intentions }\end{array}$ & Australia & Online survey & $\begin{array}{l}537, \\
\text { Australian } \\
\text { tourism } \\
\text { online } \\
\text { community } \\
\text { members }\end{array}$ & SEM & $\begin{array}{l}\text { Attitude, } \\
\text { Quality belief, } \\
\text { Trust, Utility, } \\
\text { Corporate social } \\
\text { responsibility }\end{array}$ & $\begin{array}{l}\text { Purchase } \\
\text { intention }\end{array}$ & ATT & $\begin{array}{l}\text { Tourists treat specific information posted } \\
\text { by customers as most useful and } \\
\text { trustworthy. Their purchase intention is } \\
\text { influenced by their attitude toward the } \\
\text { resort and their belief in CSR }\end{array}$ \\
\hline 8 & $\begin{array}{l}\text { Ayeh, Au \& Law } \\
\text { (2013) }\end{array}$ & $\begin{array}{l}\text { To investigate the factors } \\
\text { influencing consumers' } \\
\text { use of consumer- } \\
\text { generated media for } \\
\text { media planning }\end{array}$ & USA & Online survey & $\begin{array}{l}535, \mathrm{US} \\
\text { tourists }\end{array}$ & SEM & $\begin{array}{l}\text { Attitude, } \\
\text { Perceived } \\
\text { enjoyment, } \\
\text { Perceived } \\
\text { similarity, } \\
\text { Perceived ease } \\
\text { of use, } \\
\text { Usefulness, } \\
\text { Trust worthiness }\end{array}$ & Intention & TAM & $\begin{array}{l}\text { Using control variables such as age, } \\
\text { education, gender and internet usage } \\
\text { frequency, it found that perceived } \\
\text { enjoyment and ease of use have greater } \\
\text { effects on CGM for travel planning. }\end{array}$ \\
\hline 9 & Ku (2011) & $\begin{array}{l}\text { To investigate the effect } \\
\text { of virtual community on } \\
\text { travel decision }\end{array}$ & Taiwan & Online survey & $\begin{array}{l}435, \\
\text { Taiwanese } \\
\text { online forum } \\
\text { users }\end{array}$ & SEM & $\begin{array}{l}\text { Behavioural } \\
\text { intention, Flow } \\
\text { experience } \\
\text { orientation, } \\
\text { Perceived } \\
\text { enjoyment, } \\
\text { Perceived } \\
\text { usefulness }\end{array}$ & $\begin{array}{l}\text { Actual } \\
\text { participation }\end{array}$ & TAM & $\begin{array}{l}\text { Flow experience, perceived enjoyment } \\
\text { are positively related to use the } \\
\text { community. Also consumers } \\
\text { behavioural intention influences their } \\
\text { actual participation in the community }\end{array}$ \\
\hline 10 & Chen, Shang \& Li & To investigate the & Taiwan & Online survey & 179 , & SEM & Perceived & Intention to & e-WOM & Novelty, understandability and interest \\
\hline
\end{tabular}




\begin{tabular}{|c|c|c|c|c|c|c|c|c|c|c|}
\hline & (2014) & $\begin{array}{l}\text { characteristics of travel } \\
\text { blogs that influences } \\
\text { travel decisions. }\end{array}$ & & & $\begin{array}{l}\text { Taiwanese } \\
\text { students }\end{array}$ & & $\begin{array}{l}\text { enjoyment of } \\
\text { blog, Novelty, } \\
\text { Reliability, } \\
\text { Understandabili } \\
\text { ty, } \\
\text { Interestingness }\end{array}$ & visit & & $\begin{array}{l}\text { elements in a blog affect behavioural } \\
\text { intention to visit }\end{array}$ \\
\hline 11 & $\begin{array}{l}\text { Jalilvand \& Samiei } \\
\text { (2012) }\end{array}$ & $\begin{array}{l}\text { To investigate the impact } \\
\text { of electronic WOM } \\
\text { (eWOM) on a tourism } \\
\text { destination choice }\end{array}$ & Iran & Face-to-face & $\begin{array}{l}296, \text { inbound } \\
\text { tourists in } \\
\text { Iran }\end{array}$ & SEM & $\begin{array}{l}\text { Attitude, } \\
\text { Subjective } \\
\text { norm, Perceived } \\
\text { behavioural } \\
\text { control, } \\
\text { electronic word } \\
\text { of mouth }\end{array}$ & $\begin{array}{l}\text { Intention to } \\
\text { travel }\end{array}$ & TPB & $\begin{array}{l}\text { eWOM, attitude, subjective norm, } \\
\text { perceived behavioural control, were } \\
\text { found to positively influence attitudes } \\
\text { towards visiting the destination. }\end{array}$ \\
\hline 12 & $\begin{array}{l}\text { Sparks \& Browning } \\
\text { (2011) }\end{array}$ & $\begin{array}{l}\text { To investigate the effect } \\
\text { of online reviews on } \\
\text { hotel booking intentions } \\
\text { and perception of trust }\end{array}$ & Australia & Online survey & $\begin{array}{l}5500, \\
\text { Australian } \\
\text { tourists }\end{array}$ & ANOVA & $\begin{array}{l}\text { Framing, } \\
\text { Valence, Trust }\end{array}$ & $\begin{array}{l}\text { Booking } \\
\text { intention }\end{array}$ & eWOM & $\begin{array}{l}\text { Consumers are influenced by negative } \\
\text { reviews especially when are the reviews } \\
\text { are negative }\end{array}$ \\
\hline 13 & $\begin{array}{l}\text { Hsiao, Lu \& Lan } \\
\text { (2013) }\end{array}$ & $\begin{array}{l}\text { To determine how } \\
\text { storytelling blogs affect } \\
\text { readers' intention to } \\
\text { adopt travel products }\end{array}$ & Taiwan & Online survey & $\begin{array}{l}368, \\
\text { Taiwanese }\end{array}$ & SEM & $\begin{array}{l}\text { Attitude, } \\
\text { Empathy, } \\
\text { Perceived } \\
\text { aesthetics, } \\
\text { Narrative } \\
\text { structure, Sell } \\
\text { reference }\end{array}$ & Intention & TRA & $\begin{array}{l}\text { Well-designed layout can effectively } \\
\text { increase readers' intention and positive } \\
\text { feelings. }\end{array}$ \\
\hline 14 & $\begin{array}{l}\text { Casalo, Flavian \& } \\
\text { Guinaliu (2011) }\end{array}$ & $\begin{array}{l}\text { To investigate factors } \\
\text { influencing tourists to } \\
\text { follow online } \\
\text { community information } \\
\text { for travel planning }\end{array}$ & Spain & Online survey & $\begin{array}{l}456, \text { online } \\
\text { community } \\
\text { members }\end{array}$ & SEM & $\begin{array}{l}\text { Attitude, } \\
\text { Perceived } \\
\text { usefulness, } \\
\text { Trust }\end{array}$ & $\begin{array}{l}\text { Intention to } \\
\text { follow advise }\end{array}$ & TAM & $\begin{array}{l}\text { Travelers' attitude toward advise in an } \\
\text { online community strongly influences } \\
\text { intention }\end{array}$ \\
\hline 15 & $\begin{array}{l}\text { Zhao, Wang, Guo \& } \\
\text { Law (2015) }\end{array}$ & $\begin{array}{l}\text { To investigate the impact } \\
\text { of reviews on travelers' } \\
\text { hotel booking intentions }\end{array}$ & China & $\begin{array}{l}\text { Face-to-face } \\
\text { and online } \\
\text { survey }\end{array}$ & $\begin{array}{l}\text { 269, Chinese } \\
\text { hotel bookers }\end{array}$ & $\begin{array}{l}\text { Correlati } \\
\text { on, } \\
\text { regressio } \\
\mathrm{n} \\
\text { analyses }\end{array}$ & 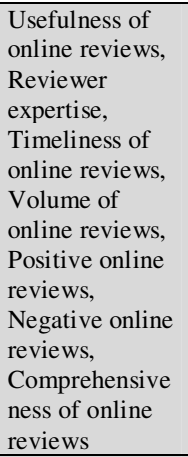 & $\begin{array}{l}\text { Booking } \\
\text { intentions }\end{array}$ & eWOM & $\begin{array}{l}\text { No relation between negative online } \\
\text { reviews and booking intentions. Also, } \\
\text { relation between positive reviews and } \\
\text { booking intentions was not statistically } \\
\text { significant }\end{array}$ \\
\hline 16 & Wang (2015) & $\begin{array}{l}\text { The investigate the } \\
\text { influence of eWOM on } \\
\text { outbound tourists' } \\
\text { intention to visit a }\end{array}$ & China & Online survey & $\begin{array}{l}195, \text { Chinese } \\
\text { outbound } \\
\text { travelers to } \\
\text { Finland }\end{array}$ & SEM & $\begin{array}{l}\text { Attitude, } \\
\text { Argument } \\
\text { quality, Source } \\
\text { credibility }\end{array}$ & Intention & ELM, TPB & $\begin{array}{l}\text { Attitude about the destination was } \\
\text { influenced by eWOM }\end{array}$ \\
\hline
\end{tabular}




\begin{tabular}{|c|c|c|c|c|c|c|c|c|c|c|}
\hline & & destination & & & & & & & & \\
\hline 17 & Ho \& Lee (2015) & $\begin{array}{l}\text { To investigate the } \\
\text { influence of travel blogs } \\
\text { on purchase intention }\end{array}$ & Taiwan & Online survey & $\begin{array}{l}288, \\
\text { Taiwanese } \\
\text { bloggers }\end{array}$ & SEM & $\begin{array}{l}\text { e-Loyalty, } \\
\text { Interactivity, e- } \\
\text { Satisfaction, } \\
\text { Information } \\
\text { quality }\end{array}$ & $\begin{array}{l}\text { Purchase } \\
\text { intention }\end{array}$ & RQ & $\begin{array}{l}\text { Information, e-trust, e-satisfaction, e- } \\
\text { loyalty have influence on purchase } \\
\text { intention }\end{array}$ \\
\hline 18 & Lin (2007) & $\begin{array}{l}\text { To examine the impact } \\
\text { of online information } \\
\text { quality features on the } \\
\text { sustainability of virtual } \\
\text { communities }\end{array}$ & Taiwan & Online survey & $\begin{array}{l}165 \text {, virtual } \\
\text { community } \\
\text { members }\end{array}$ & SEM & $\begin{array}{l}\text { Sense of } \\
\text { belonging } \\
\text { Perceived } \\
\text { usefulness, } \\
\text { Perceived ease } \\
\text { of use, } \\
\text { Information } \\
\text { quality, System } \\
\text { quality, Service } \\
\text { quality, Offline } \\
\text { activities }\end{array}$ & Intention & TAM & $\begin{array}{l}\text { Perceived usefulness, ease of use and } \\
\text { offline activities are the determinants of } \\
\text { sustainability in virtual communities. }\end{array}$ \\
\hline 19 & Wu \& Chang (2005) & $\begin{array}{l}\text { To explore the factors } \\
\text { that affect the experience } \\
\text { of flow and how flow } \\
\text { affects the transaction } \\
\text { intentions of the } \\
\text { community members }\end{array}$ & Taiwan & Online & $\begin{array}{l}286 \text { online } \\
\text { community } \\
\text { members }\end{array}$ & SEM & $\begin{array}{l}\text { (Flow)Enjoyme } \\
\text { nt, Time } \\
\text { distortion, } \\
\text { Machine } \\
\text { Interactivity, } \\
\text { Person } \\
\text { interactivity, } \\
\text { Ability, } \\
\text { Benevolence, } \\
\text { Integrity, } \\
\text { Predictability }\end{array}$ & Intention & FLOW & $\begin{array}{l}\text { Interactivity and trust affect community } \\
\text { members' relationship }\end{array}$ \\
\hline 20 & Chung \& Koo (2015) & $\begin{array}{l}\text { To examine how social } \\
\text { media influences travel } \\
\text { information search from } \\
\text { a value perspective }\end{array}$ & $\begin{array}{l}\text { Republic of } \\
\text { Korea }\end{array}$ & Online & $\begin{array}{l}695 \text {, Korean } \\
\text { residents }\end{array}$ & SEM & $\begin{array}{l}\text { Information } \\
\text { reliability, } \\
\text { Enjoyment, } \\
\text { Complexity, } \\
\text { Effort, } \\
\text { Perceived value, }\end{array}$ & Usage & VAM & $\begin{array}{l}\text { Social media use in travel information } \\
\text { search has been perceived as benefits } \\
\text { (information reliability \& enjoyment) } \\
\text { and sacrifices (complexity, perceived } \\
\text { effort). All have been shown to affect } \\
\text { travel information search. However, } \\
\text { enjoyment makes direct effect on social } \\
\text { media use. }\end{array}$ \\
\hline 21 & Wang (2012) & $\begin{array}{l}\text { To investigate the } \\
\text { affective, cognitive and } \\
\text { cyber-interactive } \\
\text { elements influencing } \\
\text { travel blog readers' } \\
\text { behavioural intention to } \\
\text { travel }\end{array}$ & China & Online survey & $\begin{array}{l}323, \text { blog } \\
\text { participants }\end{array}$ & SEM & $\begin{array}{l}\begin{array}{l}\text { Building } \\
\text { affective } \\
\text { images, }\end{array} \\
\text { Building } \\
\text { cognitive } \\
\text { images, } \\
\text { Facilitating } \\
\text { interpersonal } \\
\text { interaction }\end{array}$ & $\begin{array}{l}\text { Behavioural } \\
\text { intention }\end{array}$ & eWOM & $\begin{array}{l}\text { Travel blog participants' perception of } \\
\text { destination image is a strong predictor of } \\
\text { travel intention. Building affective } \\
\text { images, cognitive images and facilitating } \\
\text { interactions significantly influenced } \\
\text { bloggers perception of destination } \\
\text { images }\end{array}$ \\
\hline 22 & $\begin{array}{l}\text { Jalilvand, Samiei, } \\
\text { Dini \& Manzari } \\
(2012)\end{array}$ & $\begin{array}{l}\text { To examine the } \\
\text { relationship between } \\
\text { eWOM, destination }\end{array}$ & Iran & Face-to-face & $\begin{array}{l}264, \\
\text { international } \\
\text { tourists in }\end{array}$ & SEM & $\begin{array}{l}\text { Destination } \\
\text { image, Attitude } \\
\text { toward }\end{array}$ & $\begin{array}{l}\text { Travel } \\
\text { intention }\end{array}$ & e-WOM & $\begin{array}{l}\text { eWOM positive influenced destination } \\
\text { image, destination image and attitude } \\
\text { positively influence travel intention }\end{array}$ \\
\hline
\end{tabular}




\begin{tabular}{|c|c|c|c|c|c|c|c|c|c|c|}
\hline & & $\begin{array}{l}\text { image, tourist attitude } \\
\text { and travel intention }\end{array}$ & & & Iran & & $\begin{array}{l}\text { destination, } \\
\text { eWOM }\end{array}$ & & & \\
\hline \multicolumn{11}{|c|}{ Consumer adoption of mobile information system in tourism (CAMIST) } \\
\hline 1 & $\begin{array}{l}\text { Kim, Chung, Lee \& } \\
\text { Preis (2015) }\end{array}$ & $\begin{array}{l}\text { To investigate how } \\
\text { mobile tourism shopping } \\
\text { influences continuous } \\
\text { usage }\end{array}$ & $\begin{array}{l}\text { Republic of } \\
\text { Korea }\end{array}$ & Online survey & $\begin{array}{l}357 ; \\
\text { individuals }\end{array}$ & SEM & $\begin{array}{l}\text { Perceived } \\
\text { Usefulness, Site } \\
\text { Attachment, } \\
\text { Source } \\
\text { Credibility, } \\
\text { Argument } \\
\text { Quality. Social } \\
\text { Network } \\
\text { Involvement } \\
\text { (Moderator } \\
\text { variable) }\end{array}$ & $\begin{array}{l}\text { Continued } \\
\text { Usage of } \\
\text { Mobile } \\
\text { Tourism } \\
\text { Shopping }\end{array}$ & ELM & $\begin{array}{l}\text { Perceived usefulness positively } \\
\text { influences mobile tourism shopping as } \\
\text { also site attachment was seen to } \\
\text { positively influence mobile tourism } \\
\text { shopping }\end{array}$ \\
\hline 2 & Lai (2015) & $\begin{array}{l}\text { To examine factors } \\
\text { influencing use of } \\
\text { mobile App for tourism } \\
\text { use by extending the } \\
\text { original UTAUT model }\end{array}$ & China & $\begin{array}{l}\text { Interviewer- } \\
\text { administered } \\
\text { survey }\end{array}$ & 205; residents & SEM & $\begin{array}{l}\text { Performance } \\
\text { expectance, } \\
\text { Effort } \\
\text { expectancy, } \\
\text { Social } \\
\text { influence, } \\
\text { Facilitating } \\
\text { conditions, } \\
\text { Informativeness } \\
\text {, Entertainment }\end{array}$ & $\begin{array}{l}\text { Behavioural } \\
\text { intention }\end{array}$ & UTAUT & $\begin{array}{l}\text { Informativeness has the greatest impact } \\
\text { on Behavioural intention to use AMTG. } \\
\text { Also, PE, EE, SI and FC have all direct } \\
\text { positive effect on BI }\end{array}$ \\
\hline 3 & $\begin{array}{l}\text { Chang, Chou, Yeh \& } \\
\text { Tseng (2016) }\end{array}$ & $\begin{array}{l}\text { To examine the factors } \\
\text { influencing usage } \\
\text { intention of Taiwan } \\
\text { Medical travel app }\end{array}$ & Taiwan & $\begin{array}{l}\text { Self- } \\
\text { administered } \\
\text { survey }\end{array}$ & $\begin{array}{l}366 \text {; Chinese } \\
\text { medical } \\
\text { tourists }\end{array}$ & SEM & $\begin{array}{l}\text { Attitude, } \\
\text { Perceived } \\
\text { behavioural } \\
\text { control, App } \\
\text { involvement } \\
\text { Perceived ease } \\
\text { of use, } \\
\text { Perceived } \\
\text { usefulness, } \\
\text { social influence, } \\
\text { E-wom, Mobile } \\
\text { self efficiency }\end{array}$ & $\begin{array}{l}\text { Usage } \\
\text { intention }\end{array}$ & DTPB & $\begin{array}{l}\text { The higher the behavioural control the } \\
\text { higher the usage intention. When the } \\
\text { PEOU \& PU are high, usage intention } \\
\text { would also be high }\end{array}$ \\
\hline 4 & $\begin{array}{l}\text { Okazaki \& Hirose } \\
\text { (2009) }\end{array}$ & $\begin{array}{l}\text { To examine the factors } \\
\text { affecting the use of } \\
\text { mobile internet as a } \\
\text { media source for travel } \\
\text { decisions }\end{array}$ & Japan & & $\begin{array}{l}\text { 992, Japanese } \\
\text { tourists }\end{array}$ & SEM & $\begin{array}{l}\begin{array}{l}\text { Attitude } \\
\text { (traditional }\end{array} \\
\text { media, mobile } \\
\text { internet, PC } \\
\text { internet), } \\
\text { Satisfaction } \\
\text { (traditional } \\
\text { media, mobile } \\
\text { internet and PC } \\
\text { internet) }\end{array}$ & $\begin{array}{l}\text { Habitual } \\
\text { Usage of } \\
\text { mobile } \\
\text { internet }\end{array}$ & GT, NT & $\begin{array}{l}\text { Satisfaction from mobile internet and } \\
\text { attitude towards mobile internet will be } \\
\text { stronger for female than for male. }\end{array}$ \\
\hline 5 & Chung, Koo \& Kim & To investigate the impact & Republic of & Face-to-face & 101 , & SEM & Perceived & Behaviour & UDT & Escape, event attraction are significantly \\
\hline
\end{tabular}




\begin{tabular}{|c|c|c|c|c|c|c|c|c|c|c|}
\hline & (2014) & $\begin{array}{l}\text { of Booth Recommender } \\
\text { System (BRS) service on } \\
\text { usage behavior }\end{array}$ & Korea & & $\begin{array}{l}\text { exhibition } \\
\text { visitors }\end{array}$ & & $\begin{array}{l}\text { usefulness, } \\
\text { Threats to } \\
\text { freedom of } \\
\text { choice, } \\
\text { Information } \\
\text { gain, Escape, } \\
\text { Event attraction }\end{array}$ & & & $\begin{array}{l}\text { related to perceived usefulness while } \\
\text { information was not significant. } \\
\text { Perceived usefulness directly mediate on } \\
\text { unplanned behavior }\end{array}$ \\
\hline 6 & No \& Kim (2014) & $\begin{array}{l}\text { To examine } \\
\text { determinants of intention } \\
\text { to adopt smartphone for } \\
\text { travel purposes }\end{array}$ & $\begin{array}{l}\text { Republic of } \\
\text { Korea }\end{array}$ & Online survey & 400 , travelers & SEM & $\begin{array}{l}\text { Usefulness, } \\
\text { Ease of use, } \\
\text { Social } \\
\text { influence, } \\
\text { Satisfaction, }\end{array}$ & $\begin{array}{l}\text { Intention to } \\
\text { use } \\
\text { smartphone }\end{array}$ & UTAUT & $\begin{array}{l}\text { Usefulness, ease of use, social influence } \\
\text { and satisfaction influence travelers' use } \\
\text { of smartphone for travel planning }\end{array}$ \\
\hline 7 & $\begin{array}{l}\text { Kim, Park \& } \\
\text { Morrison (2008) }\end{array}$ & $\begin{array}{l}\text { To examine the factors } \\
\text { influencing the adoption } \\
\text { of mobile technology in } \\
\text { tourism }\end{array}$ & USA & Online survey & $\begin{array}{l}283, \\
\text { American } \\
\text { travelers }\end{array}$ & SEM & $\begin{array}{l}\text { Attitude, } \\
\text { Perceived } \\
\text { usefulness, } \\
\text { Perceived ease } \\
\text { of use, } \\
\text { Technology } \\
\text { experience, Trip } \\
\text { experience }\end{array}$ & $\begin{array}{l}\text { Intenti } \\
\text { travel }\end{array}$ & TAM & $\begin{array}{l}\text { Trip experience and technology } \\
\text { experience positively influenced } \\
\text { perceived performance and perceived } \\
\text { ease of use. }\end{array}$ \\
\hline 8 & $\begin{array}{l}\text { Lu, Mao, Wang \& Hu } \\
\text { (2015) }\end{array}$ & $\begin{array}{l}\text { To investigate factors } \\
\text { that influence travel app } \\
\text { adoption by tourists } \\
\text { visiting rural tourism } \\
\text { sites in China }\end{array}$ & China & Face-to-face & 613 & SEM & $\begin{array}{l}\text { Self-efficacy, } \\
\text { Performance } \\
\text { outcome, } \\
\text { Personal } \\
\text { outcome } \\
\text { (Information, } \\
\text { Navigation, } \\
\text { Marketing, } \\
\text { Socialization, } \\
\text { Safety, } \\
\text { Entertainment, } \\
\text { Transaction) } \\
\text { Advantage, } \\
\text { Compatibility, } \\
\text { Complexity, } \\
\text { Social norms } \\
\end{array}$ & $\begin{array}{l}\text { Intention to } \\
\text { travel }\end{array}$ & $\begin{array}{l}\text { TAM, IDT, } \\
\text { SCT }\end{array}$ & $\begin{array}{l}\text { PU, PEOU and compatibility were found } \\
\text { to influence travel app adoption. } \\
\text { However, compatibility was the best } \\
\text { perception-based indicator of attitude to } \\
\text { adopt travel app. in the SCT, } \\
\text { performance outcome expectation were } \\
\text { better, high expectation for transaction } \\
\text { functions. Social norms did not have } \\
\text { impact. }\end{array}$ \\
\hline
\end{tabular}

IDT - Innovation Diffusion Theory, TAM - Technology Acceptance Model; EUS - End-User Satisfaction; ELM - Elaboration Likelihood Model; TRA Theory of Reasoned Action; TPB - Theory of Planned Behaviour; INT - Intentions to use social media; TCT - Transaction Cost Theory; CDT - Cognitive Dissonance Theory; ECM - Expectation Confirmation Model; DTPB - Decomposed Theory of Planned Behaviour; UTAUT - Unified Theory of Acceptance and Use of Technology; TTPT - Trust Transfer Process Theory; MGB - Model of Goal-Directed Behaviour; GT - Gender Theory; NT - Niche Theory, UDT - Unplanned Decision Theory; SOR - Stimulus-Organism Response framework; ATT - Attitude; CNTT - Cognitive-Normative Tourism Typology; SERVQUAL - Service quality model, ADC - Ad Design Content; RQ - Relationship Quality; WPI - Website Performance Index; MRT - Media Richness Theory; SIM - Social Influence Model; VAM - Value-based Adoption Model 
Appendix II

\begin{tabular}{|c|c|c|c|c|}
\hline Author/year & $\begin{array}{l}\text { Year of } \\
\text { coverage }\end{array}$ & $\begin{array}{l}\text { No. of } \\
\text { articles } \\
\text { reviewed }\end{array}$ & $\begin{array}{l}\text { ICT } \\
\text { domain/ } \\
\text { area }\end{array}$ & Purpose and key findings \\
\hline Frew, 2000 & 1980-1999 & 665 & $\begin{array}{l}\text { ICT } \\
\text { application } \\
\text { in tourism } \\
\text { services }\end{array}$ & $\begin{array}{l}\text { The review covered both } \\
\text { ICT-related and non-ICT- } \\
\text { related articles in tourism } \\
\text { studies. Papers were } \\
\text { segmented by scale, scope } \\
\text { and sources, with the } \\
\text { internet seen as } \\
\text { potentially redefining the } \\
\text { tourism industry in the } \\
\text { near future }\end{array}$ \\
\hline $\begin{array}{l}\text { Leung \& Law, } \\
2007\end{array}$ & $1985-2004$ & 55 & $\begin{array}{l}\text { ICT } \\
\text { application } \\
\text { in tourism } \\
\text { services }\end{array}$ & $\begin{array}{l}\text { Publications on } \\
\text { networking were greater } \\
\text { in number, with 1995- } \\
2004 \text { seeing the highest } \\
\text { publication }\end{array}$ \\
\hline $\begin{array}{l}\text { Buhalis \& Law, } \\
2008\end{array}$ & $1987-2007$ & 149 & $\begin{array}{l}\text { ICT } \\
\text { application } \\
\text { in tourism } \\
\text { services }\end{array}$ & $\begin{array}{l}\text { Review of ICT studies in } \\
\text { tourism. It found that e- } \\
\text { tourism is focused on } \\
\text { consumer-centric } \\
\text { technologies that allow } \\
\text { organizations to interact } \\
\text { with their customers }\end{array}$ \\
\hline Law et al. 2009 & & 215 & $\begin{array}{l}\text { ICT } \\
\text { application } \\
\text { in tourism } \\
\text { services }\end{array}$ & $\begin{array}{l}\text { Papers were categorized } \\
\text { by consumer, } \\
\text { technological and supplier } \\
\text { perspectives. ICT was } \\
\text { considered to play a } \\
\text { dominant role in customer } \\
\text { satisfaction }\end{array}$ \\
\hline I & 1996-2009 & 75 & $\begin{array}{l}\text { Tourism } \\
\text { website }\end{array}$ & $\begin{array}{l}\text { The study reviewed } \\
\text { publications on website } \\
\text { evaluation. It noted that } \\
\text { the counting method of } \\
\text { evaluating websites } \\
\text { dominated these studies }\end{array}$ \\
\hline Leung et al., 2013 & $2007-2011$ & 44 & $\begin{array}{l}\text { Social } \\
\text { Media in } \\
\text { tourism }\end{array}$ & $\begin{array}{l}\text { Social media was } \\
\text { considered very useful in } \\
\text { customer engagement and } \\
\text { retention }\end{array}$ \\
\hline Pesonen (2013) & $2000-2011$ & 188 & $\begin{array}{l}\text { ICT \& Market } \\
\text { Segmentation } \\
\text { in tourism }\end{array}$ & $\begin{array}{l}\text { Using ICT in tourism } \\
\text { services. }\end{array}$ \\
\hline
\end{tabular}

Law et al. $2014 \quad$ 2009-2013 107

ICT Customer, technological application and supplier perspectives in tourism were also reviewed, with 


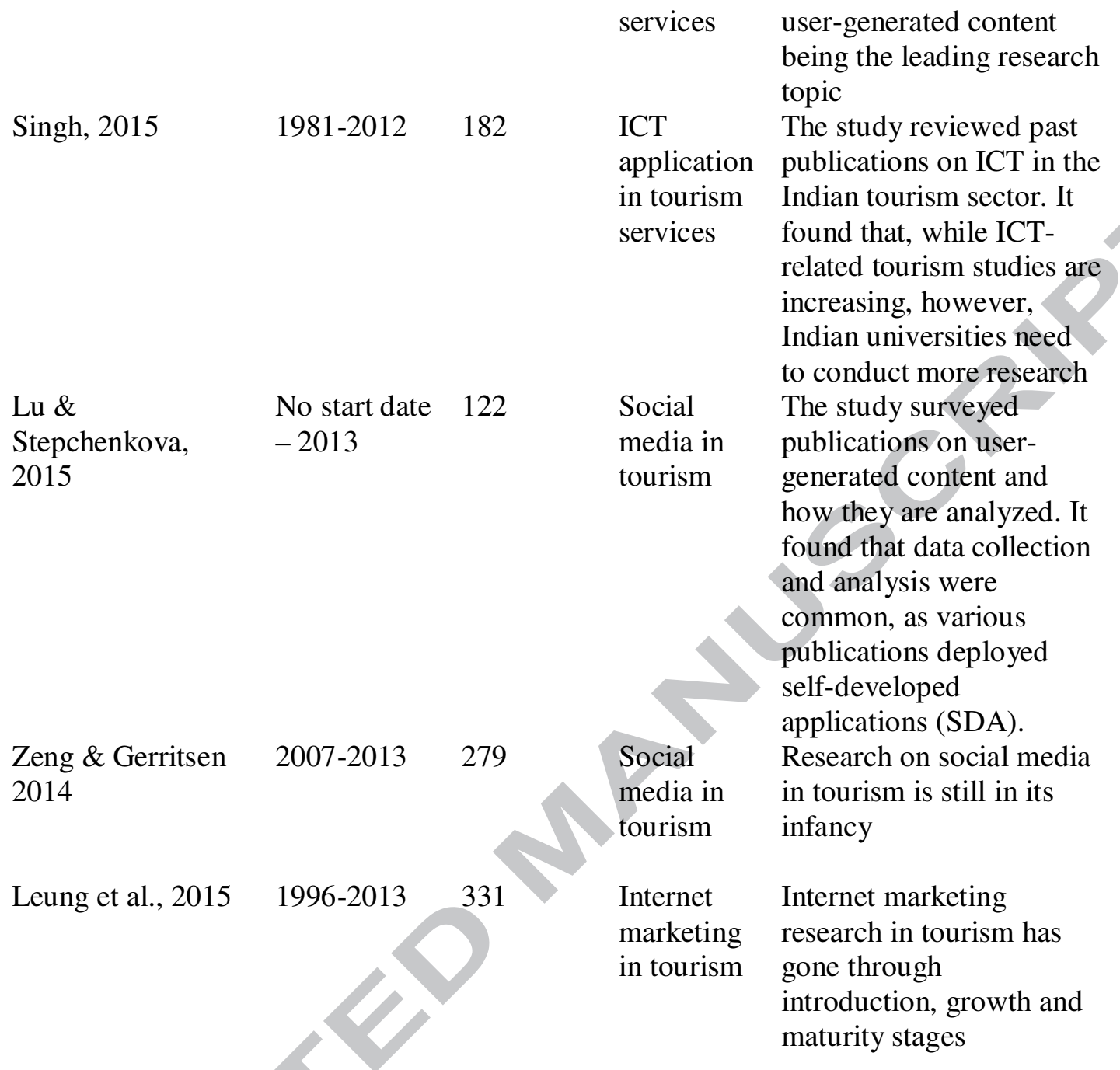

Appendix III

\begin{tabular}{cl}
\hline S/N & \\
\hline \multicolumn{3}{c}{ Tourism-based journals } \\
1 & Tourism Management \\
2 & International Journal of Hos \\
3 & International Journal of Tou \\
4 & Journal of Hospitality and T \\
5 & Journal of Travel \& Tourism \\
6 & Journal of Travel Research \\
7 & Current Issues in Tourism \\
8 & International Journal of Con \\
9 & Journal of Air Transport M \\
10 & Asia Pacific Journal of Tour \\
11 & International Journal of Hospit \\
12 & Journal of Destination Mark \\
13 & Journal of Hospitality Mark \\
14 & Journal of Hospitality \& To \\
15 & Journal of Vacation Marketing \\
16 & Leisure Sciences \\
& \\
Non-tourism based journals \\
1 & Telematics and Informatics \\
2 & Internet Research
\end{tabular}

Journal 
Online Information Review

The Service Industries Journal

Computers in Human Behaviour

Asia Pacific Journal of Marketing \& Logistics

Behaviour \& Information Technology

Industrial Management and Data Systems

Information Systems and E-Business Management

International Journal of Retail \& Distribution Management

Journal of Business Research

Journal of Statistics \& Management Systems

Journal of Systems and Information Technology

Technological Forecasting \& Social Change 


\section{Highlights}

- The review provides a conceptual framework on e-tourism research

- Research on e-tourism is grouped into three classifications

- Research on these three groups are uneven

- Synthesis of theories, theories and frameworks provided 